Article

\title{
Textiles and Fabrics for Enhanced Structural Glass Facades: Potentials and Challenges
}

\author{
Chiara Bedon ${ }^{1, *(1)}$ and Vlatka Rajčić ${ }^{2}$ \\ 1 Department of Engineering and Architecture, University of Trieste, 34127 Trieste, Italy \\ 2 Faculty of Civil Engineering, Department of Structures, University of Zagreb, 10000 Zagreb, Croatia \\ * Correspondence: chiara.bedon@dia.units.it; Tel.: +39-040-558-3837
}

Received: 9 June 2019; Accepted: 26 June 2019; Published: 28 June 2019

\begin{abstract}
The use of textiles in architecture can cover a wide set of solutions and functions, spanning from buildings, towards geotechnical, aeronautic or automotive fields, etc. Special applications involve textiles in the health care or dressing scenarios. A multitude of other functions can then be found relatively for the use of textiles in building engineering and facades. As far as traditional facades or roofs composed of glass are taken into account, textiles offer a relevant number of potential uses that are specifically focused on energy, acoustic, insulation and even structural goals, in addition to pure architectural objectives. It is known that glass is relatively versatile, but has intrinsic needs and thermo-physical and mechanical features that require dedicated design methods, towards safe design purposes. Glass itself, in the form of constructional material, cannot be directly compared to other consolidated solutions for buildings. The same concept applies to textiles, and to their use to enhance other building components. Besides the key advantages deriving from the use of textiles in glass facades and envelopes-in the form of light, thermal or acoustic insulation, or energy efficiency-special care must be spent for specific structural requirements and performances. In some cases, textiles can in fact offer enhanced resistance to ordinary glass structures. In other conditions, textiles in combination with glass can ensure also enhanced acoustic and thermal performances. A multidisciplinary design approach able to properly fit several objectives should be considered. This paper aims at exploring the actual knowledge on glass textiles, with a focus on available tools and research trends, with careful consideration for structural glass facade applications.
\end{abstract}

Keywords: structural performance parameters; textiles; glass; buildings; design loads; material properties; experiments; Finite Element (FE) numerical modelling

\section{Introduction}

In the last two decades, the production and use of textiles for construction showed a relatively fast increase, due to the availability of different products and manufacturing techniques, the capacity of reproducing even complex geometrical shapes and several benefits for several building materials [1-3]. Textile fibres and meshes are in fact largely used to reinforce and enhance the capacity of load-bearing components made of traditional materials, such as, concrete, masonry or timber.

The typical application consists of textile reinforced mortars in which fibre filaments act in place of steel rebars (see Section 2 and [4-6]). The actual result can take the form of efficient technical solutions that are suitable especially for existing (and often historical) buildings needing massive, structural retrofit interventions, especially in regions with high seismic hazards ([7-10]). Major advantages are represented by reduced weight, lack of corrosion phenomena, durability, etc. [11-13].

In the field of structural applications for buildings, textiles represent a strong source of innovation for conventional materials and techniques, in the same way in which glass started to prove a certain load-bearing role in construction (Figure 1). 


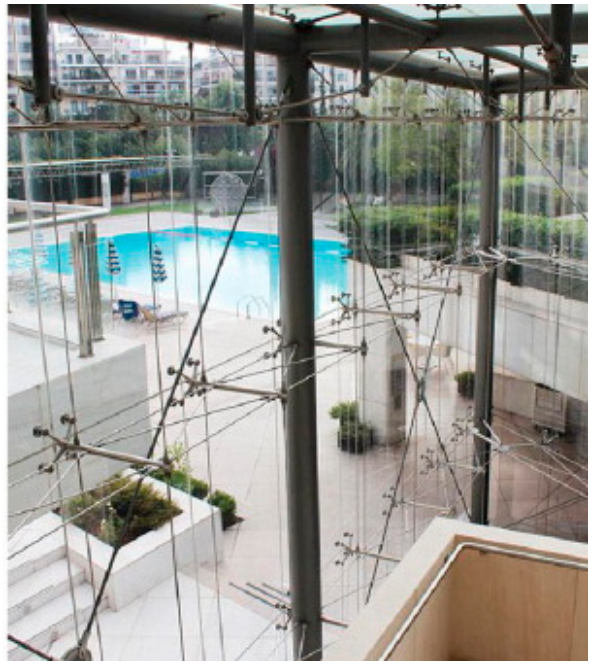

(a)

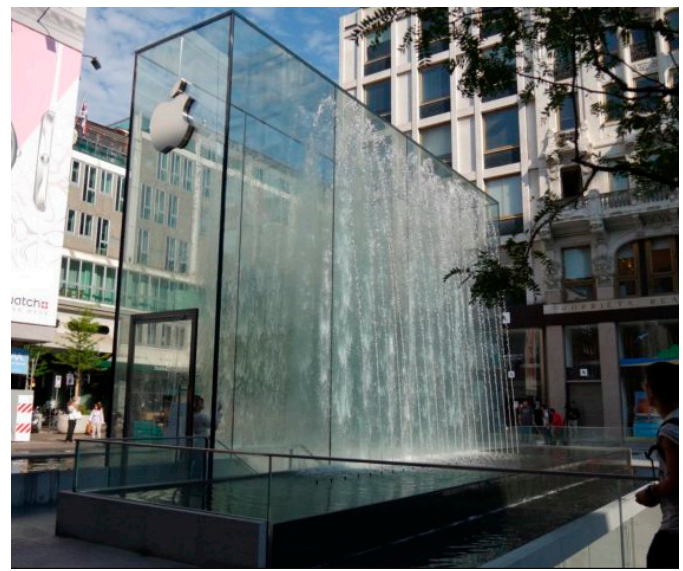

(c)

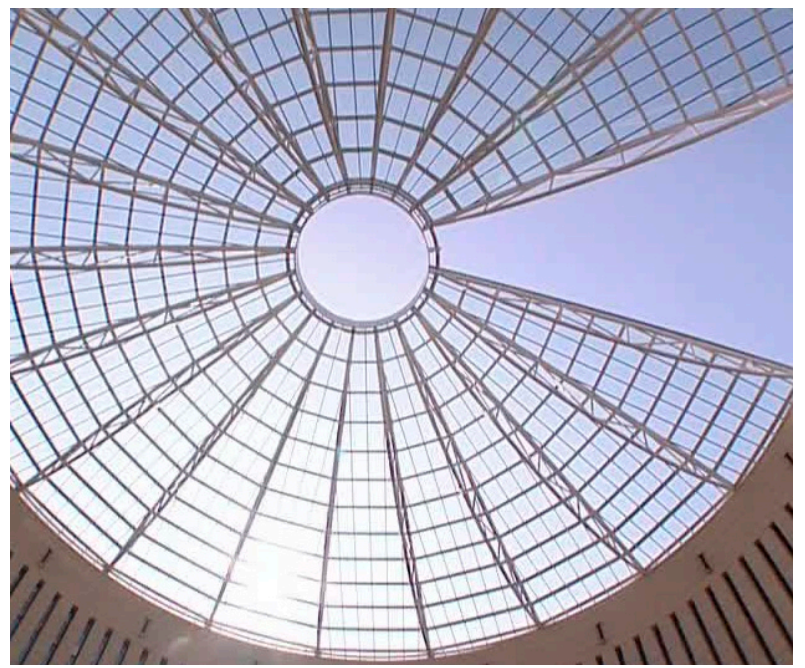

(b)

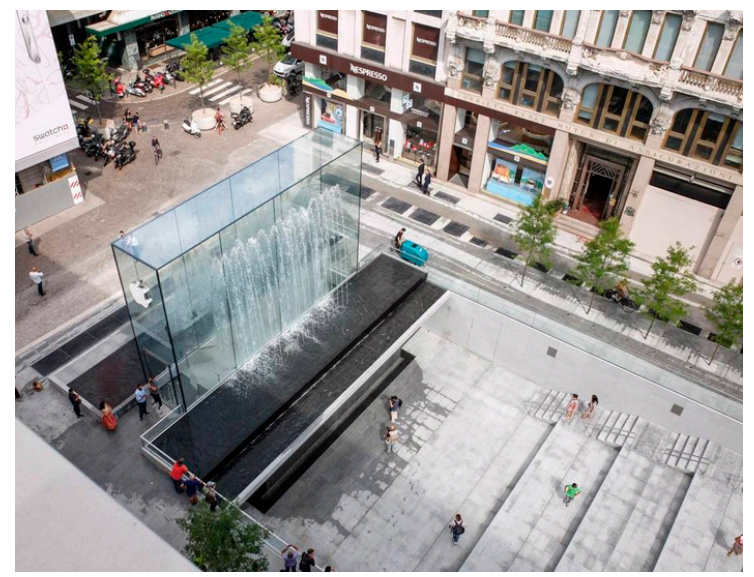

(d)

Figure 1. Glass in buildings for (a) facades (reproduced from [14] with permission from Elsevier, license n. 4580680789049, May 2019); (b) roofs or (c,d) other load-bearing architectures (example for Piazza Liberty in Milano, Italy).

A relatively recent and wide scenario of applications of textiles and fabrics can be found in glass facades and assemblies (Figure 2). Their key feature is represented by the realization of textile architecture, where, compared to traditional material systems in which the primary goal is the structural retrofit of (even massive) load-bearing components, specific tasks must be taken into account.

On one side, the transparency and light balance of glazed systems should satisfy strict performance indicators that are intrinsic of glass enclosures. At the same time, glass intended as a load-bearing material is characterized by a well-known tensile brittleness, and typically small thickness-to-size ratios that should be assessed with the support of dedicated design approaches [14-16]. Enhanced structural performances and mechanical features should then be ensured for structural glass systems under extreme loads, such as shocks or severe natural hazards [17-20]. The possible occurrence of coupled thermo-mechanical phenomena in glass, as a direct or indirect effect of the textile/coating systems in use, may also have crucial consequences, given the high sensitivity of glass systems to thermal shock phenomena or other degradation effects with severe temperature gradients [21-23]. In any case, shading components and other facade members as a whole, should offer appropriate structural behaviours, at the local (component) and global (assembly) levels [14,24]. 


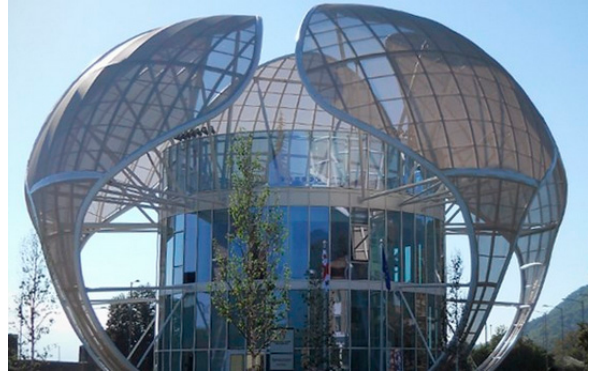

(a)

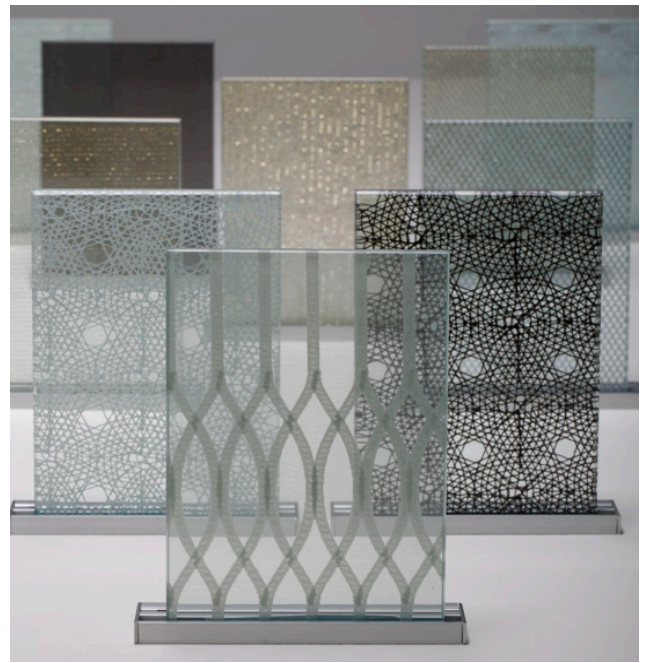

(c)

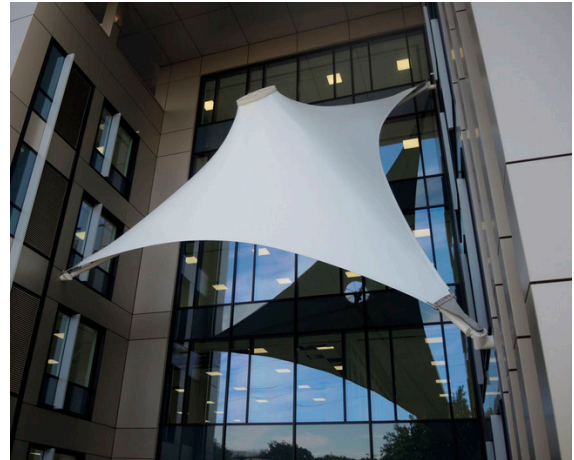

(b)

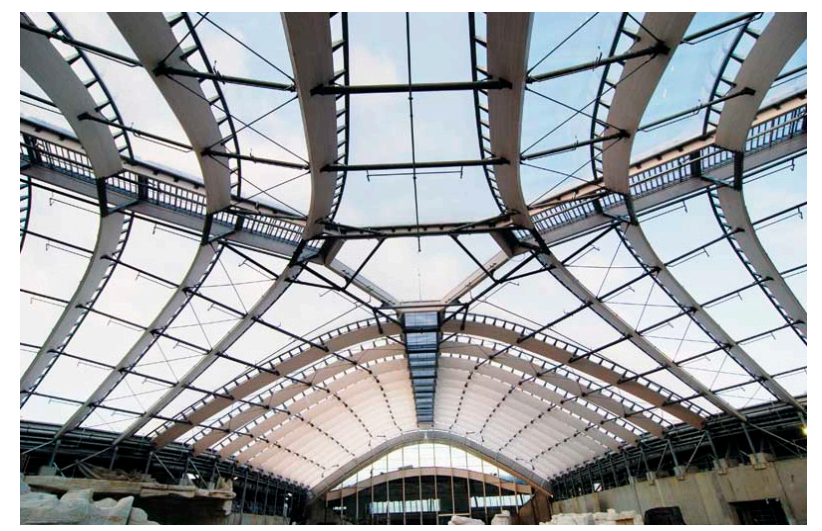

(d)

Figure 2. Selected examples of textiles in glass facades and assemblies: $(\mathbf{a}, \mathbf{b})$ textile facades with shading membranes (reproduced from [25,26]); (c) glass textile samples (Tex Glass®reproduced from [27]); and (d) textiles for enhanced acoustic comfort of glass halls (reproduced from [28]).

In this regard, the paper aims at presenting an overview on the actual possibilities and trends for the advanced use of textiles in combination with glass for buildings (i.e., Figure 2). In doing so, the typical (consolidated, or more recent) textile applications and available techniques for textiles-based retrofit of constructional components made of concrete, masonry or timber are briefly recalled in Section 2. The attention is then focused on the use of textiles with or in replacement of glass facades and load-bearing components, with evidence of existing research studies and major challenges (Sections 3 and 4).

According to Figures 1 and 2, glass is a relatively versatile material, in the same way of textiles and fabrics. The final practical result of glass-textile design strategies takes the form of a wide series of possible applications, where textiles can be intended to satisfy single or specific performance requirements. Within the overall built environment, some typical examples of modern architecture are aimed at ensuring decorative goals only. In some other cases, thermal and lightening comfort levels can represent the primary objective. Some literature research studies recently explored the mechanical efficiency of load-bearing glass elements with embedded fabrics. The dedicated methods and advanced analysis techniques are finally required for bulletproof textile curtains, aimed at minimizing the typically high vulnerability of glass facades and fenestrations under shock. Within such a complex and in-progress scenario, the paper includes part of a research study financially supported by the EU-COST Action "CONTEXT - European Network to connect research and innovation efforts on advanced smart textiles" (2018-2022), see also [29]. 


\section{Textiles and Fabrics with Traditional Buildings Materials}

The performance assessment of textile-reinforced cementitious composites is an established research topic, with over 30 years of efforts aimed at improving their mechanical behaviour and overall capacity. Both 2D or 3D textile fibre meshes can be used to reinforce a given mortar matrix (see for example Figure 3a). Glass-fiber reinforced polymer (GFRP) components represent one of the most efficient solutions, due to their high tensile resistance, but the implementation of novel materials with enhanced benefits is also of interest [30-34], and attracted in the last few years the attention of several research investigations inclusive of experimental, analytical and finite element (FE) numerical studies. The thermo-mechanical structural behaviour of these assemblies under unfavourable conditions can be also relevant and should be properly taken into account $[35,36]$. Textile reinforced concrete can then be efficient also for improving the capacity of sandwich panels [37]. As a general issue, however, the bonding properties of these textiles for enhanced mortars are still an open research topic, especially with respect to textile composition, prestressing, etc., see for example [38].

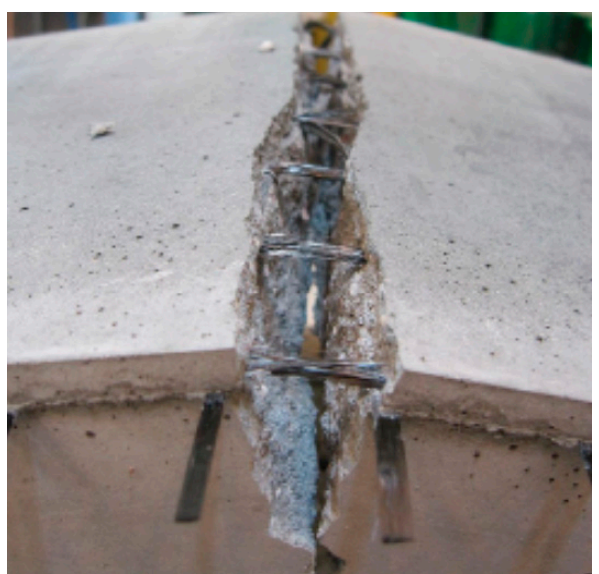

(a)

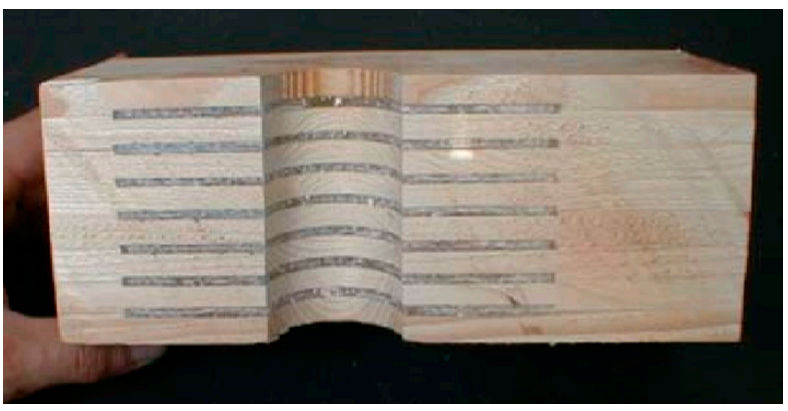

(c)
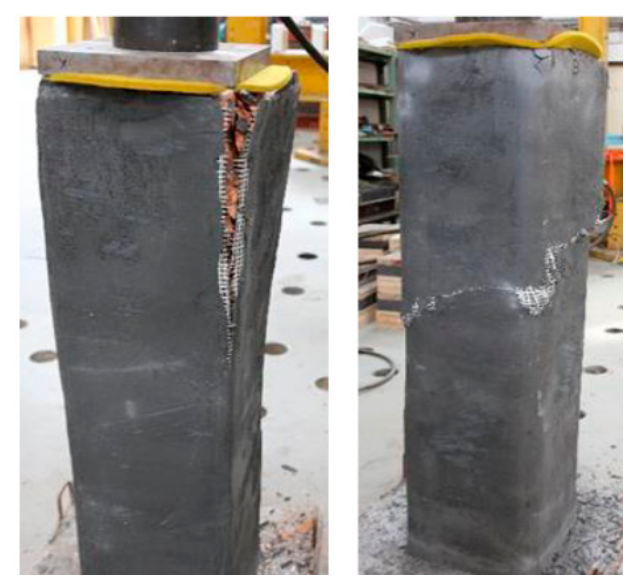

(b)

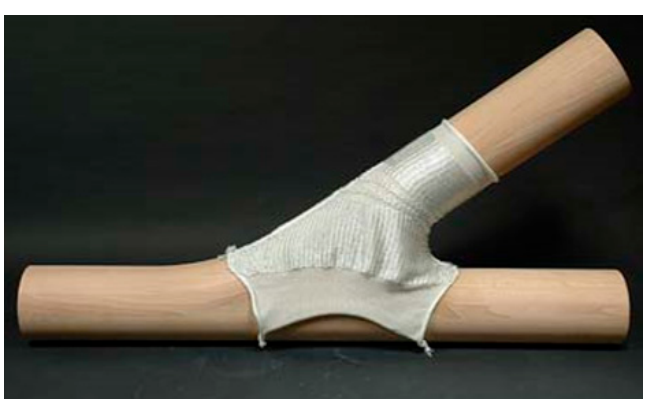

(d)

Figure 3. Examples of (a) textile reinforced concrete slab with carbon fiber mesh (reproduced from [39]), or (b) masonry column (reproduced from [40] with permission from Elsevier, license n. 4580730591053, May 2019), and (c,d) timber joints. (c): timber specimen with embedded knitted fabric reinforcement (cross-section; reproduced from [41]); (d) 3D knitted reinforcement for a solid connection (reproduced from [42] with permission from Springer Nature, license n. 4580731288540, May 2019).

A certain analogy can be found in the use and requirements of textile reinforced mortars for the retrofit of masonry structures (Figure 3b). The design issue is of interest especially for existing buildings, due to the need of structurally efficient, feasible and durable solutions that could be implemented to enhance the capacity of historical masonry assemblies, including stone walls or other typologies [43-47]. 
In the case of timber structures, textiles can offer certain structural benefits especially in the form of reinforced joints, see Figure $3 c$ or Figure $3 d$ and [48-50]. Apart from the multitude of advantages that can derive from the use of textiles in timber engineering, however, major restrictions and limits could derive from the different thermal performance of the involved materials. Apart from the availability of consolidated knowledge for textile-reinforced timber structures [51], the topic still attracts novel efforts, as a result of a continuous evolution in materials and techniques, and thus a progressive development and refinement of calculation approaches.

\section{Textile Architectures and Innovative Solutions for Glass Facades}

\subsection{Glass Facades}

Glass is an amorphous and commonly transparent, solid material, whose popularity and use for load-bearing members in modern buildings is rapidly increasing. Fast advancements in knowledge and manufacturing of glass and glass-related products for buildings characterized the civil engineering sector,- especially in the last two decades. However, most of the current structural design issues are still related to ordinary or extreme loads that facades could suffer during their life time, including severe thermal exposure (Figure $4 \mathrm{a}, \mathrm{b}$ ), impact (Figure 4c), etc.

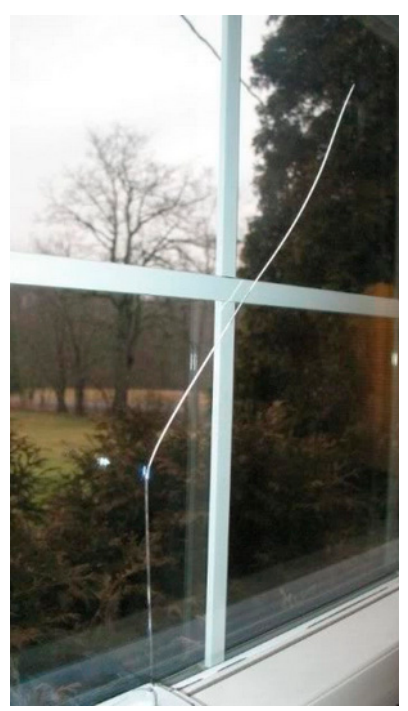

(a)

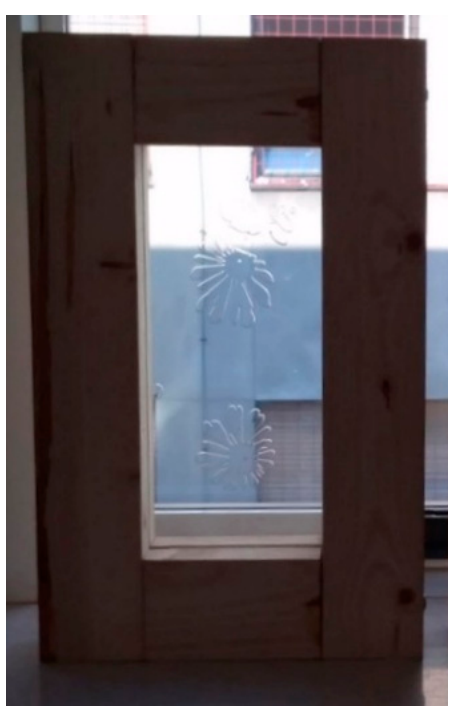

(b)

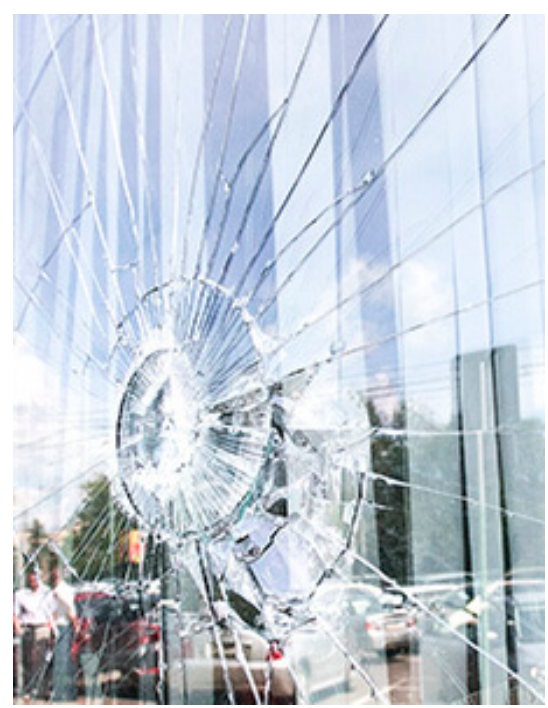

(c)

Figure 4. Examples of relevant damage in glass: (a) thermal shock; (b) melting of the interlayer foil, due to high temperature exposure (Zagreb University, Croatia-VETROLIGNUM Project); (c) fracture due to impact.

As far as these glass enclosures are designed to create a physical separation between indoor and outdoor spaces (see Figure 5), the optimal solution for major performance issues should be based on a multidisciplinary approach, inclusive among others, of thermal and energy tasks that are of primary interest for textile membranes and skins. 


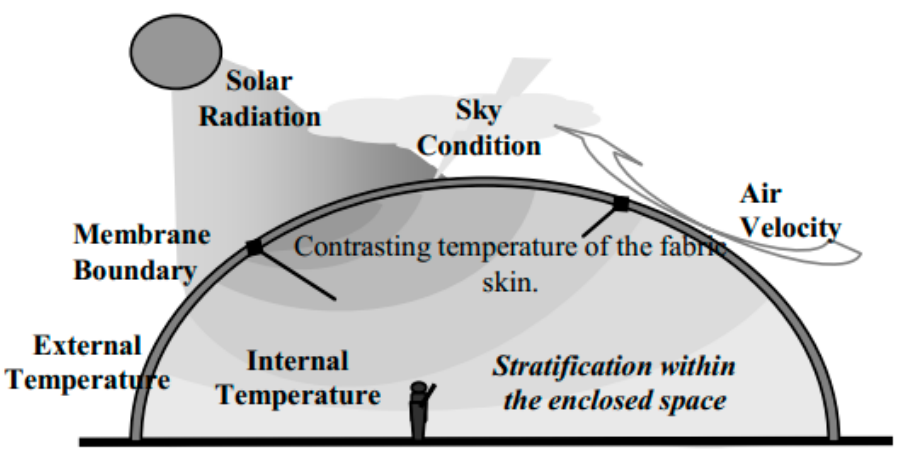

Figure 5. The influencing parameters for the overall performance assessment of textile membranes and fabric enclosures (reproduced from [52]).

\subsection{Properties of Textiles and Fabrics for Glass Facades}

It is generally recognized that textiles and foams actually represent a valuable result of recent production technologies, able to integrate with different groups of common,- but also innovative,constructional materials.

Especially in facades, the use of textiles offers a relatively wide set of possible configurations. Most of them can mainly involve shading systems and/or architectural components (Figure 2), while some others are specifically intended to improve the acoustic performance, and/or the thermal response, etc., of a given system. Based on [53] and Figure 6, it is generally recognized that the typical use of textiles and fabrics in building envelopes can aim at enhancing thermal insulation, light, and energy performances.

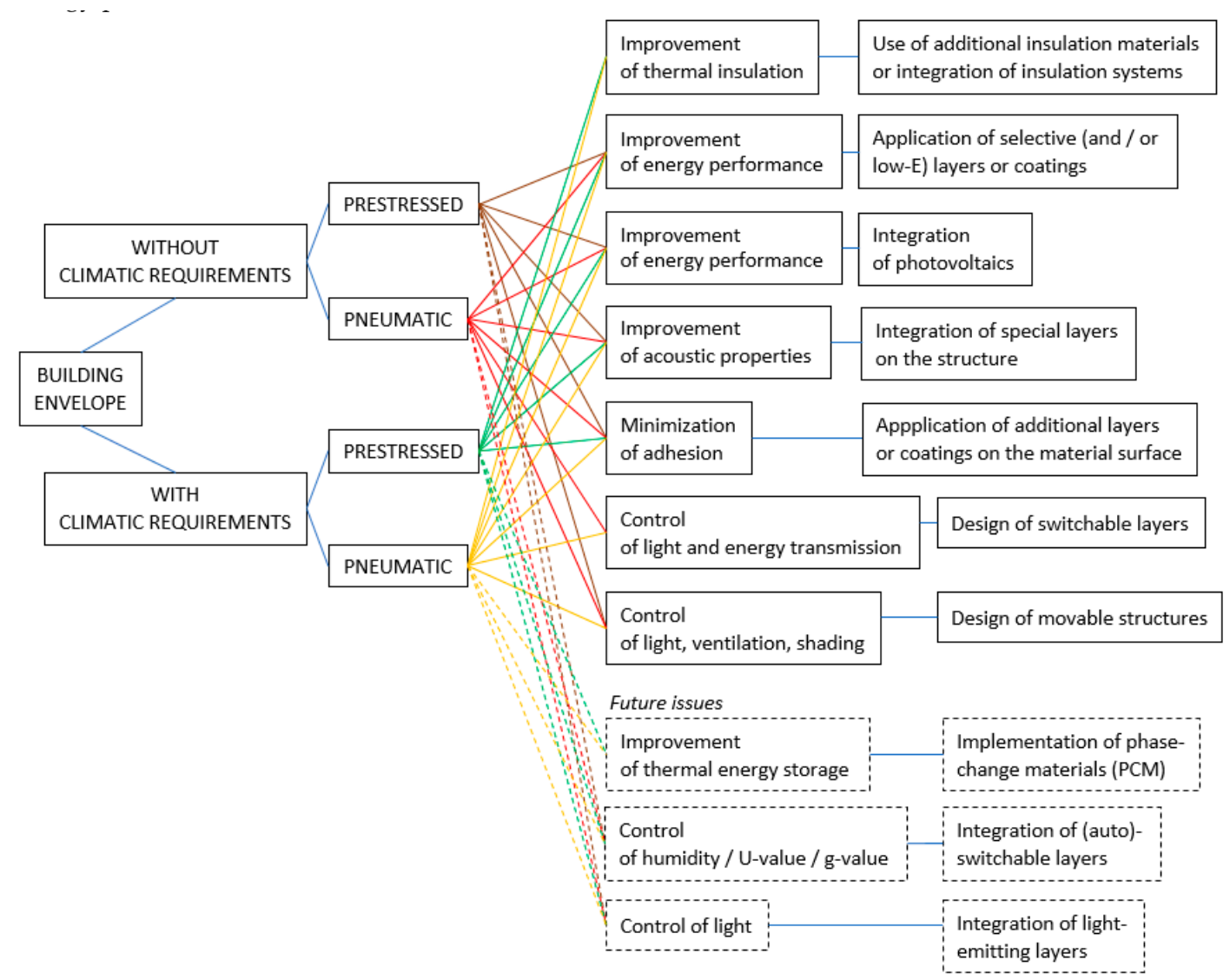

Figure 6. The use of textiles in building facades for enhanced thermal, energy and lightening performances (adapted from [53]). 
From a mechanical point of view, even further potential could derive. The major advantage is in fact that textiles are able to combine high tensile strength and elasticity, with low bending stiffness. In addition, textiles can be produced in large amounts, hence resulting in an optimal candidate for several typologies of building components and structural systems.

Certainly, an intrinsic advantage of the use of textiles in facades derives from the availability of several man-made fiber types that can be arranged in free-form solutions, see Figure 7. According to the BISFA 2009 terminology [53,54], most of the materials of technical interest are polymeric based. Otherwise, it is also possible to notice that the majority of these solutions are expected to offer architectural or shading contributions only, and hence, only a few of them are suitable for efficient structural applications. Even a limited part of such a selection can be used to obtain enhanced mechanical performances of traditional glass members and systems.

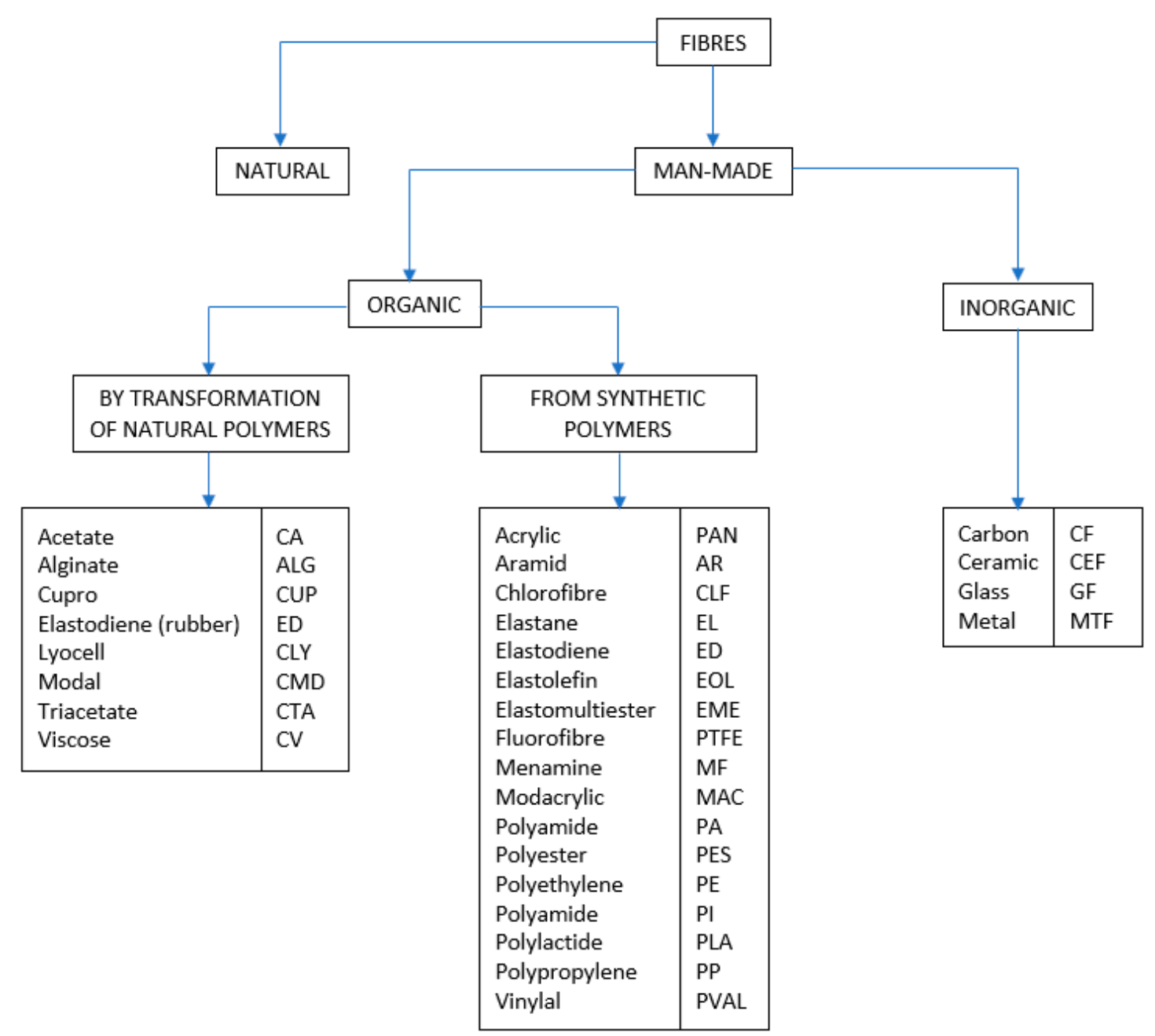

Figure 7. The common man-made fibers of conventional use for the architectural design of building envelopes (reproduced from [54]).

\section{Summary of Recent Research Efforts and Trends}

As a part of the complex systems and buildings, glass facades must ensure strict performances under the assigned boundaries and loads during their life-time. When textiles are used for enhanced textile architectures in facades, it is also clear that they should be able to mutually interact with the glazed system they belong, and adapt to possible variations in the external boundaries.

When textiles are used in buildings in the form of stand-alone membranes, these components must also offer appropriate behaviours in the form of independent building systems. The key aspects to 
assess and optimize during the design process are hence related to their capacity to withstand ordinary (but also extreme) loads, both mechanical and thermal, in their most unfavourable combinations.

\subsection{Tensile Membrane Structures}

Tensile membrane structures represent a class of building systems that are characterized by unique properties, compared to the conventional built environment. Apart from their relatively low self-weight and high flexibility, these structures are generally recognized to represent an optimal structural typology, as they are loaded only in tension. The tangible result in buildings is that shapes can be adapted to the flow of design forces, and a minimum of material can be used.

In general, membrane systems consist of a primary and a secondary structure. The primary structure is represented by the supporting system that is a sub-structure composed of steel but also aluminium, timber or concrete. The secondary system is the textile membrane (or foil) itself, that is often reinforced by cables or belts. Only in limited cases (i.e., air-supporting halls or systems with inflatable beams), the primary and secondary structures may be both realized of textile fabrics. When different materials are involved for the primary and secondary systems, their structural design has to be necessarily performed on the base of appropriate regulations, so as to achieve appropriate safety levels for each component and the overall system.

Despite the availability of several research projects and studies on tensile membrane structures, however, only a few design codes are currently available for their structural design. A common design approach, as well as a comprehensive international standard, is still needed to provide verification techniques and achieve harmonized safety levels [55]. Within CEN/TC 250/WG 5 (Structural Eurocodes-Membrane Structures), CEN/TC 248/WG 4 (Textiles and Textile Products-Coated fabrics) and the TensiNet Association (an international team of researchers, engineers, architects, material producers and manufacturers [56]), a background report was provided [55], with relevant information in support of the implementation and development of a future Eurocode for the structural design of tensile membrane structures.

The resistance of membrane structures is in fact rather complex to estimate because it depends on the static strength of materials in use,- and the latter can be conventionally estimated from tensile tests (uni- or biaxial tensile tests) but also from a combination of other influencing parameters, like the load duration, the in-service temperature, the environmental conditions, etc.

Different materials and possible combinations are used for composites and architectural fabrics. In most of the cases, basic components can consist of woven yarns made of polyester (PES), glass fiber or polytetrafluorethylene (PTFE).

Synclastic structures
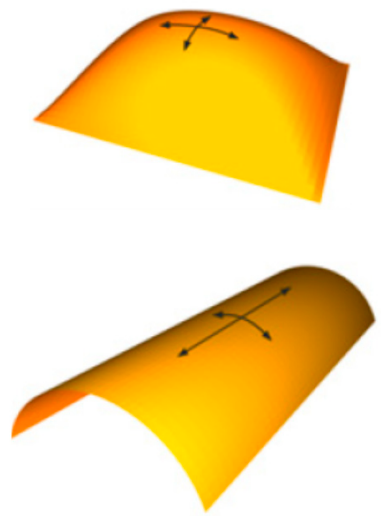

Pneumatically prestressed
Flat structures

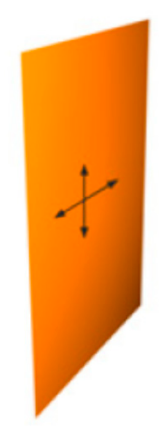

Mechanically prestressed
Anticlastic structures

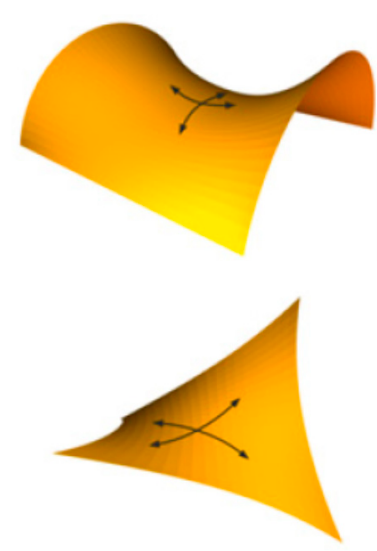

Mechanically prestressed

Figure 8. Typical shapes of membrane structures (reproduced from [57]). 
These yarns are coated with polyvinylchloride (PVC), polytetrafluorethylene (PTFE), or silicone. Within the most efficient combinations, the majority of applications according to Figure 8 can involve PVC-coated fabrics or PTFE-coated glass fabrics. For some structures (especially foldable constructions), PTFE-fabrics can be also used, including different types of coatings (like silicone or PTFE).

Regarding structural fabrics:

(1) strength values should be mainly taken from experimental tests;

(2) tensile strength values should be determined according to EN ISO 1421: 2016 (Rubber or plastics coated fabrics-Determination of tensile strength and elongation at break [58]) and the characteristic value should be determined according to EN 1990-Annex D: 2002 (Eurocode 0-Basis of Design-Annex D: Design Assisted by Testing [59]);

(3) tear strength values should be determined in accordance with EN 1875-3: 1997 (Rubber or plastics coated fabrics-Determination of tear strength-Part 3: Trapezoidal method [60]);

(4) adhesion values should be calculated as specified in the EN ISO 2411: 2017 (Rubber or plastics coated fabrics-Determination of coating adhesion [61]);

(5) in order to limit or avoid testing, finally, conservative strength values for conventional material products may be directly taken from the respective tables given by standards (when available).

Apart from the availability of consolidated products, however, it is then important to focus on structural membranes that are often produced for single projects, i.e., to adjust structural and other physical properties (i.e., light transmission) to specific design requirements. In these cases, the strength values of interest must be exclusively determined with the support of experimental tests. Special care is actually spent also for the use of auxetic materials, as efficient alternatives in the field of textile architectures, see [62-66].

\subsection{Textiles for Shading Systems in Glass Facades}

When textiles are mentioned for glass facades, the typical example is the use of woven fabrics that are installed in the front of conventional curtain walls, in the form of semi-transparent claddings with shading effects that can efficiently contribute to the energy performance of the overall system.

As such, it is generally recognized as the role that textiles can have for fashioned architectures in glass facades [67-69].

The major benefit derives from the curtain-to-fabrics gap, and from the air circulating there, with enhanced insulation performances and reduced energy costs. The shape of textiles can be designed to create a special architectural design. According to Figure 9 and [70], for example, textiles combined with foams can result in relevant mechanical and insulation performances for glass facades. However, the actual adhesion is between foams and fibers.

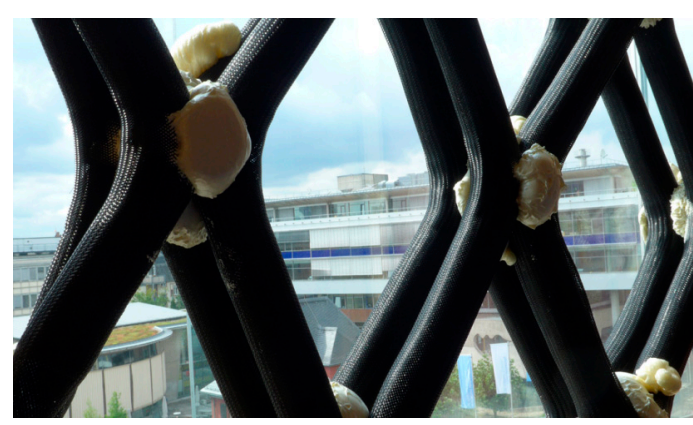

(a)

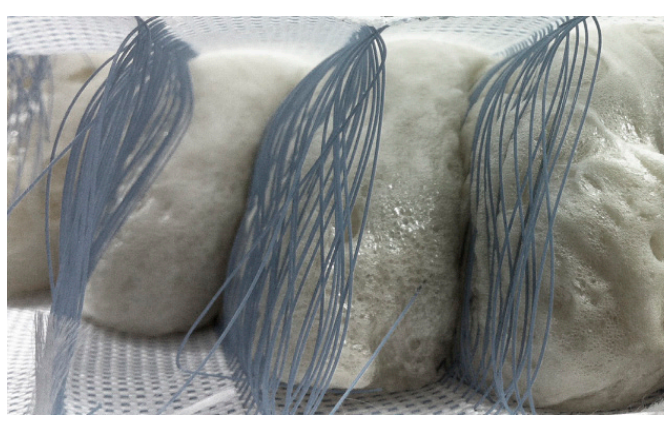

(b)

Figure 9. Textiles for free-form architectures in glass facades (reproduced from [70] under the terms and condition of CC BY-NC 4.0 license): (a) external coating composed of pressure-resistant lightweight ropes made of foamed textile sleeves, and (b) cross-sectional detail of a 3D textile-foam spacer fabric solution. 
A valid alternative can take the form of embedded textiles for glass facades, see Figure 10. The concept recalls the architectural shading of Figure 2c, where double laminated glass sections (combined with float, heat strengthened or tempered layers) are combined in the autoclave process with textile fabrics. Depending on the final layout, these textile layers are mostly intended to have a decorative role, filtering up to $99 \%$ of light. The assembled sections can have maximum dimensions up to $1.5 \mathrm{~m}$ $\times 3 \mathrm{~m}$, and find applications in stairs, balustrades, and other load-bearing glass elements in which prevailing structural requirements should be properly assessed.

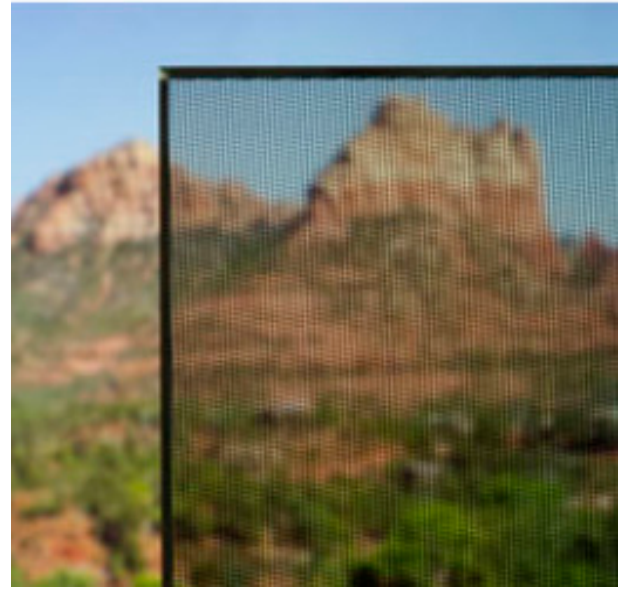

(a)

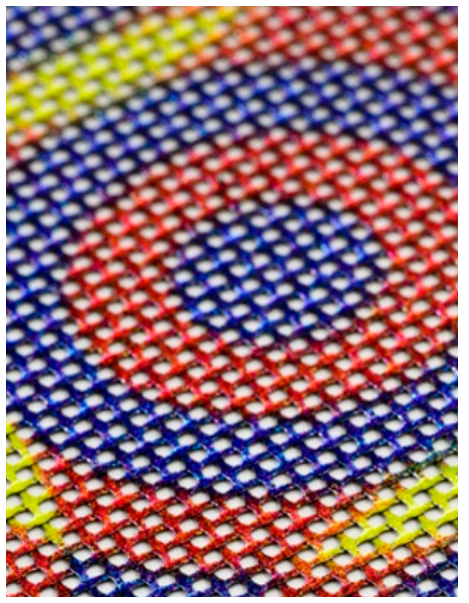

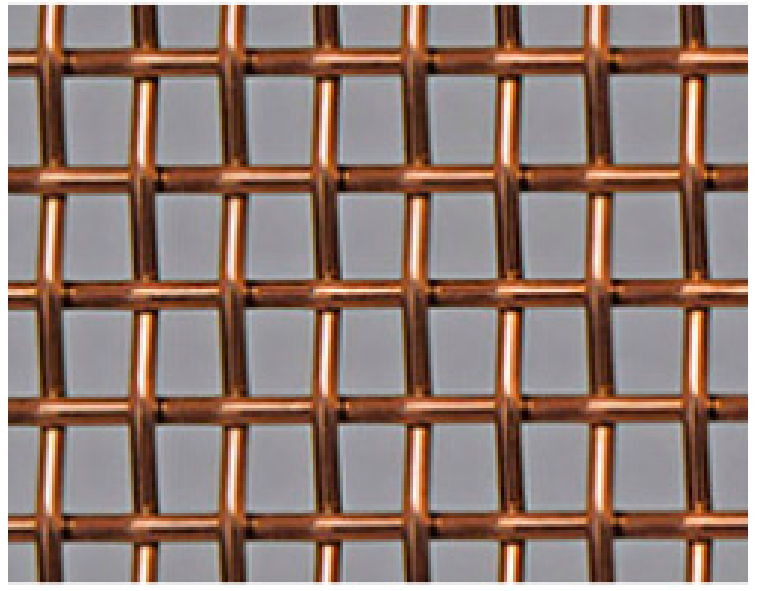

(b)
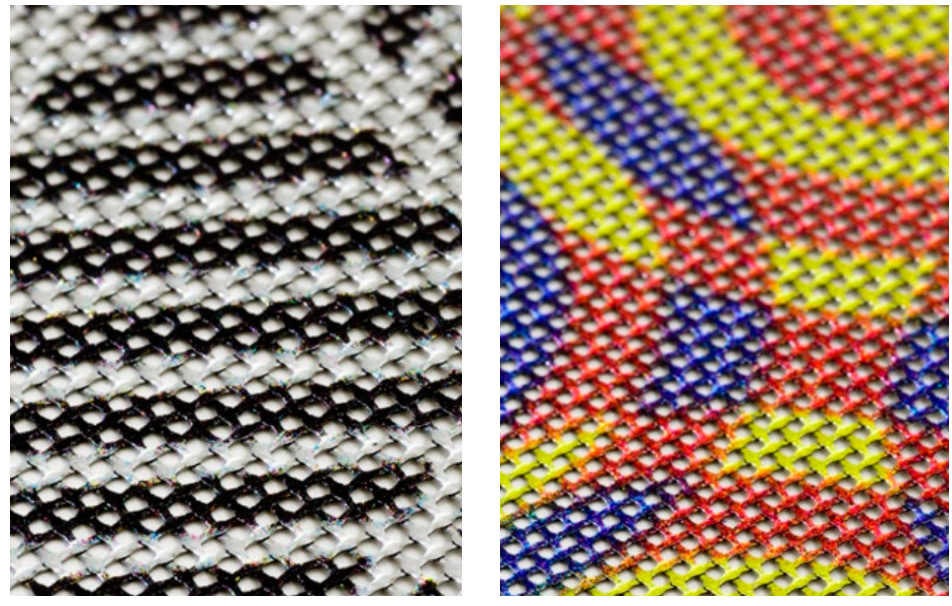

(c)

Figure 10. Examples of textile glass: (a) front view with (b) mesh detail, or (c) selection of possible coloured mesh fabrics (reproduced from [71]).

In accordance with Figure 10 and Section 4.1, these suitable options can generally consist of (i) woven glass fibres (coated with PTFE, silicon, or Teflon), or (ii) PES fabrics (PVC-coated).

From a mechanical point of view, the features of major interest are represented by the resistance and stiffness of these fibres, but also by their weight, or by the expected fire insulation capacity. Other key comfort levels to satisfy can include light and visibility, see Table 1.

As far as the above concepts are further elaborated, the final result can take the form of adaptive textiles able to ensure repeated dynamic performances within a given glass facade [72], Figure 11. According to $[73,74]$, the design challenge is hence even more complex, due to the need of combining multiple performance parameters and requests (i.e., shading, visual comfort, thermal performance, etc.) 
with typically mechanical issues and design aspects to assess for safety purposes [75], both static and dynamic.

Table 1. Typical examples of embedded textiles for enhanced glass facades (selection).

\begin{tabular}{ccccc}
\hline & $\begin{array}{c}\text { PTFE-Glass Fibre } \\
\text { Open Mesh }\end{array}$ & $\begin{array}{c}\text { PTFE-Glass Fibre } \\
\text { Open Mesh }\end{array}$ & $\begin{array}{c}\text { PTFE-Glass Fibre } \\
\text { Open Mesh }\end{array}$ & $\begin{array}{c}\text { PVC/PES Open } \\
\text { Mesh }\end{array}$ \\
\hline $\begin{array}{c}\text { Tensile strength } \\
{[\mathrm{MPa}]}\end{array}$ & $5000 / 4500$ & $1500 / 2500$ & $2400 / 1800$ & $3300 / 2200$ \\
\hline Width $[\mu \mathrm{m}]$ & 300 & 300 & 300 & 300 \\
\hline Open area $[\%]$ & $>30$ & 40 & 57 & $>30$ \\
\hline Translucency $[\%]$ & 34 & 40 & 40 & 42 \\
\hline
\end{tabular}

The concept of adaptivity is also in line with past efforts summarized in [76,77], where the mechanical performance of traditional laminated glass panels was expected to enhance under ordinary wind pressure, taking advantage of shape-memory alloy (SMA) fibres embedded in the lamination process.
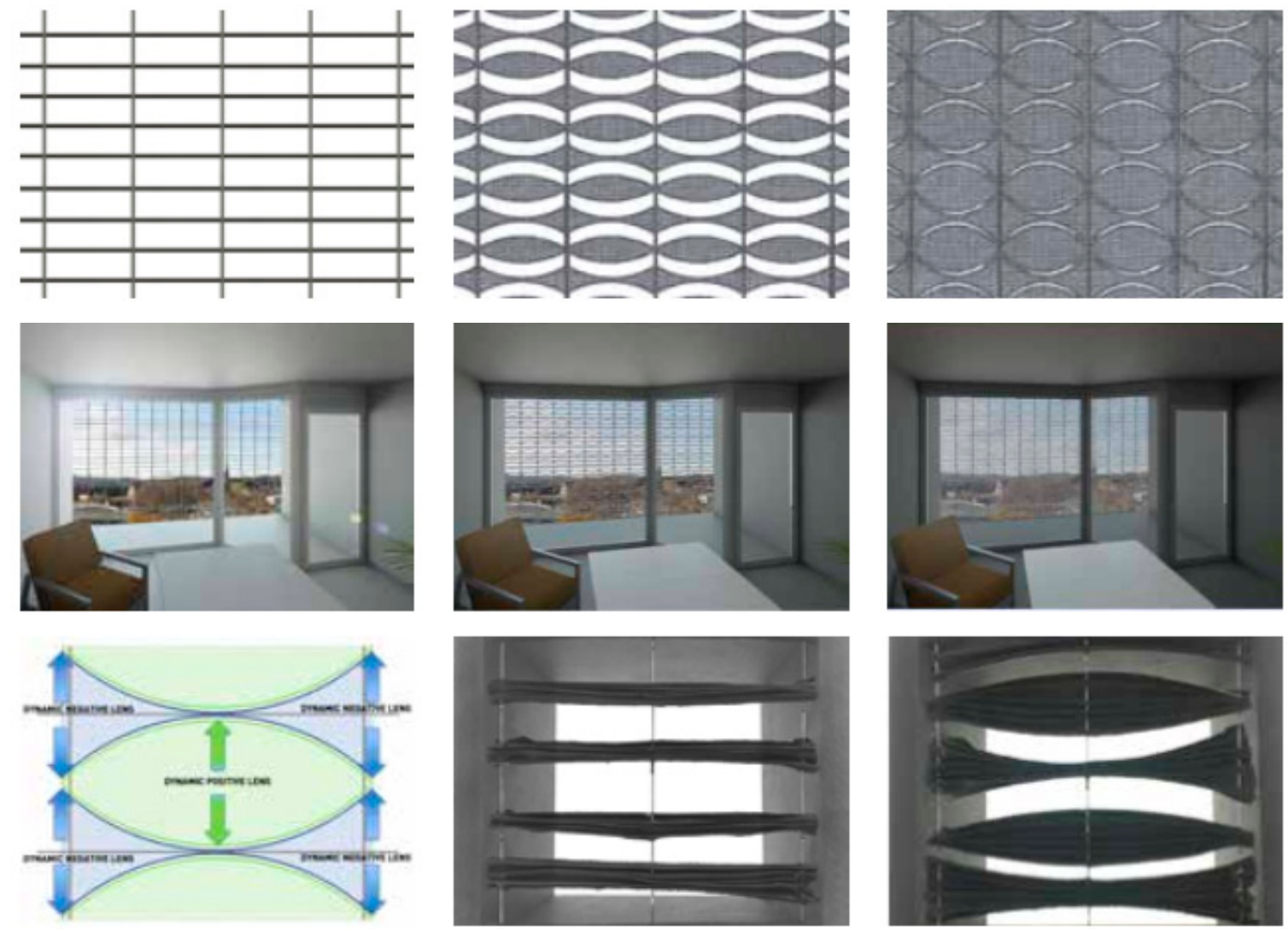

Figure 11. Prototypes of adaptive textiles composed of fabrics and bimetal strips (reproduced from [72] under the terms and condition of CC BY license).

\subsection{Textiles Embedded in Load-Bearing Glass Elements}

The concept of reinforced glass was first proposed in the early 2000s [78]. From a mechanical point of view, the design approach takes inspiration from reinforced concrete mechanisms, i.e., offering a certain redundancy and post-cracked ductility to typically brittle load-bearing members composed of glass. Early prototypes, in this regard, were characterized by the use of steel flanges and sections 
able to carry on part of the tensile loads, which enhanced the overall capacity of traditional laminated glass sections [79-81].

In [82], embedded textile rods were proposed as a potential technique to optimize such a reinforcement concept. From one side, the limited size of textile rods available on the market is certainly suitable for an embedded solution, within the conventional thicknesses of laminated glass layers (see Figure 12). At the same time, the high tensile resistance of textiles can be a guarantee for relevant post-cracked performances. In accordance with [83], however, the actual limit of the approach is represented by the brittle failure mechanisms of textiles, with respect to steel fibers. Otherwise, when the rods are properly designed with respect to the nominal glass section, it is possible to postpone the tensile failure of textiles, compared to glass, hence to ensure their activation and to obtain even large safety margins.

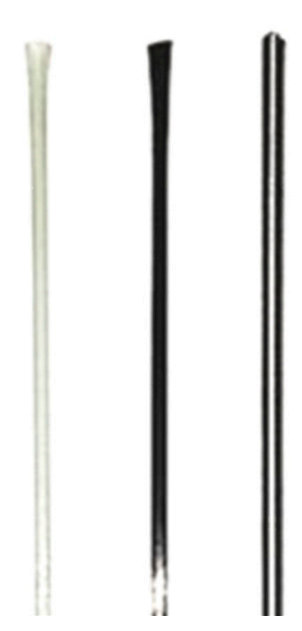

(a)

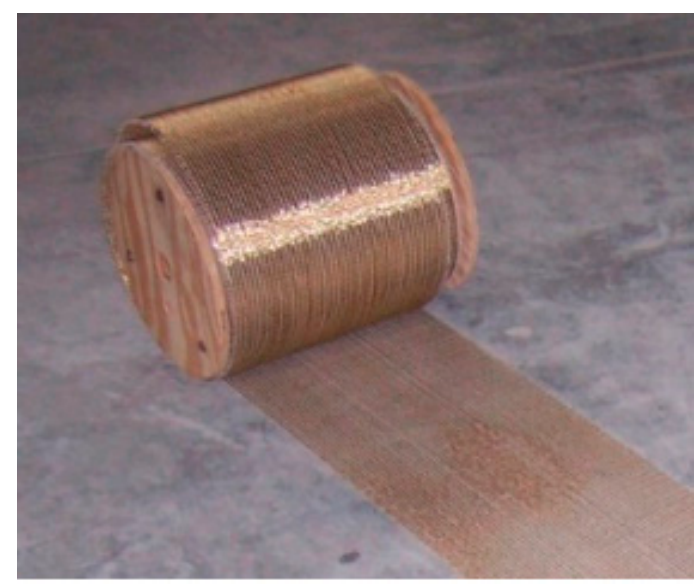

(a)

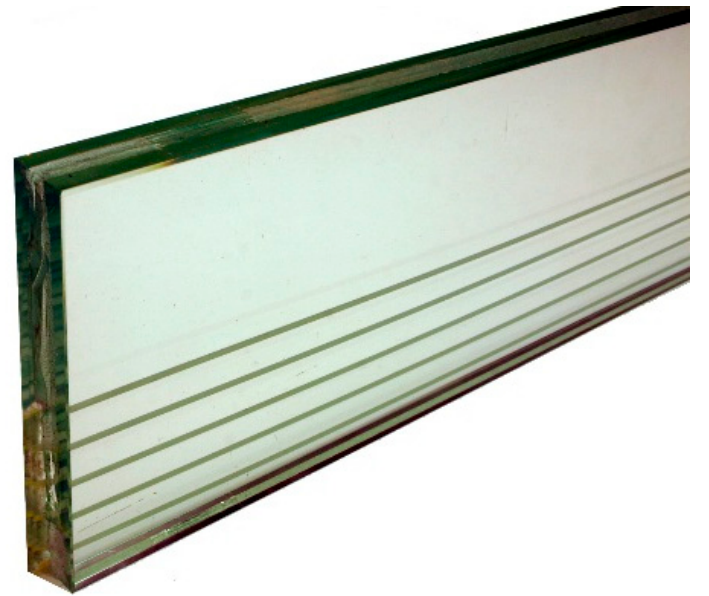

(b)

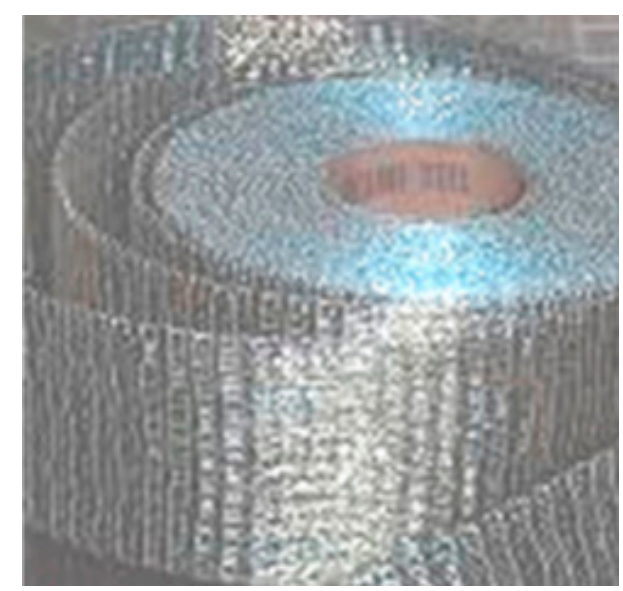

(b)

Figure 12. Examples of (a) textile rods acting as (b) embedded reinforcement in laminated glass beams (figures reproduced from [82] with permission from Elsevier, license n. 4581301243094, May 2019), as alternative to (c,d) embedded ultra-high tensile strength steel or (d) stainless steel fibers (reproduced from [83] under the terms and conditions of CC BY license).

Based on literature studies, in particular, GFRP members proved to represent an efficient solution, both for large span reinforcement applications (i.e., glass beams like Figure 12b), but also in the form of enhanced connections for the critical glass regions. In the latter case, see Figure 13 and [84], the final result can take the form of a load-bearing assembly able to preserve a maximum visibility 
and transparency for glass, while ensuring the feasibility, robustness and durability of the overall design concept.

At the current stage, however, there is a general need for more detailed investigations for all the potential applications of textiles in structural glass applications. Major limits are represented by the actual lack of standards and guideline documents with recommendations for the design and/or modelling and /or testing of such innovative solutions. In some other cases, the design concepts that have been presented in the literature are still early-stage, preliminary results that should be further assessed via extensive analyses. On the other side, the same available outcomes of literature suggest the promising development of novel glass-textiles systems for buildings.

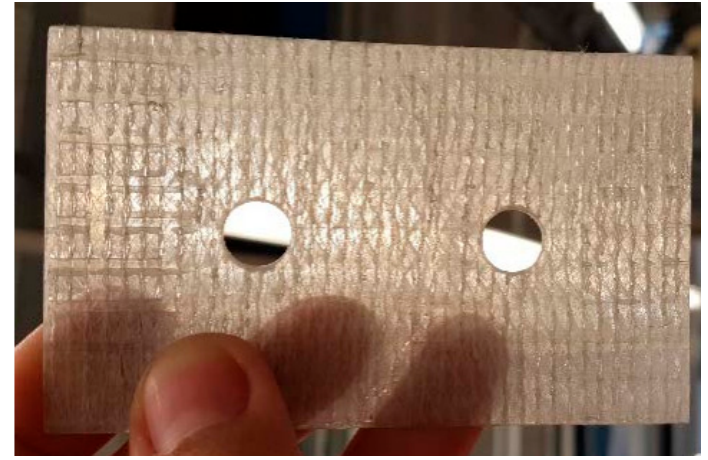

(a)

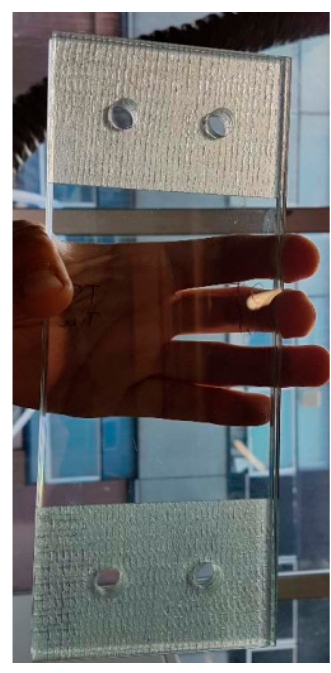

(b)

Figure 13. Examples of (a) GFRP strips (detail view) for (b) GFRP-reinforced bolted connections in structural glass members (reproduced from [84]).

\subsection{Textiles forProtective Claddings and Blast Proof Curtains}

Due to the relatively high vulnerability of glass windows and facades, one of the recent applications of textiles in existing structures can take the form of special curtains, aimed at protecting the occupants in the case of extreme loads, such as impacts and explosions (Figure 14 and [85]), but also fire [86].

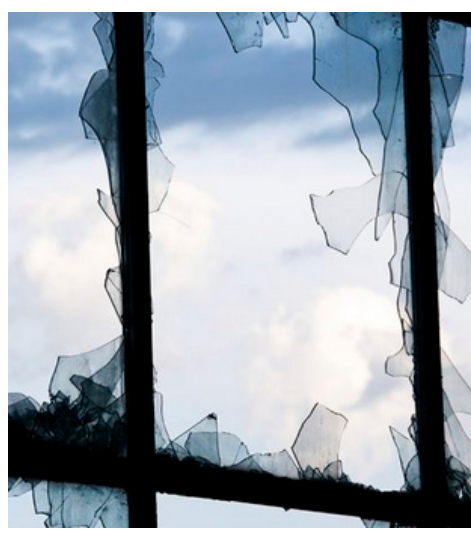

(a)

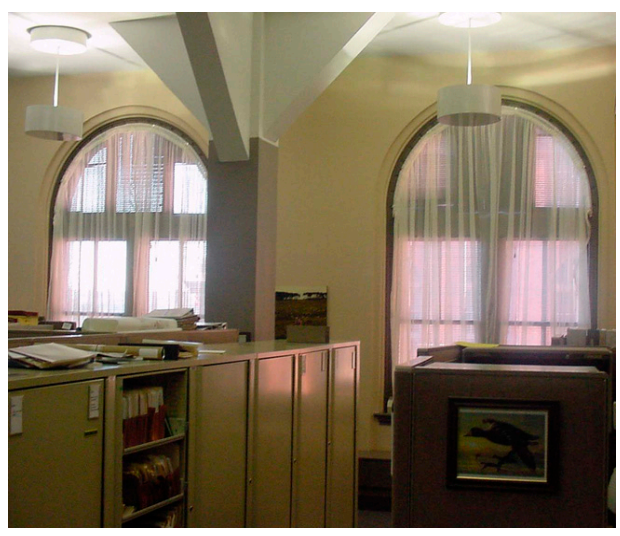

(b)

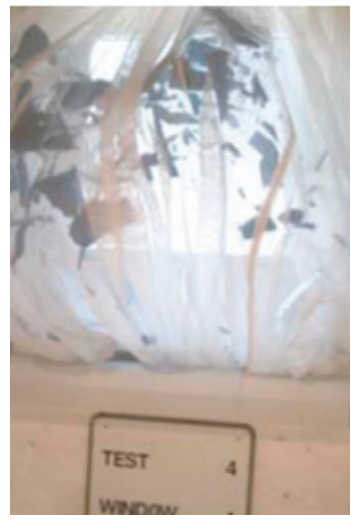

(c)

Figure 14. Glass windows and facades under shock: (a) example of severe damage of un-protected window and $(\mathbf{b}, \mathbf{c})$ enhanced performance in presence of textile curtain nets. 
For example, several non-woven technologies can be used for blast-resistant curtains [87]. The common feature of these solutions, when specifically intended for glass windows and facades, is that they are designed to protect the occupants from possible glass shards. As a result, the choice of material and the installation detailing is aimed at capturing the possible projects after impact. High strength PES fibers are generally preferred.

Experimental and FE numerical investigations were carried out by several researchers, in the last years, to explore the potential and feasibility of these textile curtains, so that they could be efficiently used as a passive protection device for glass facades, see [88-93]. Careful consideration was spent, in $[89,91]$, for the assessment of major effects and failure process of woven fabric drapes (Twaron®plain weave samples), under ballistic impact (0.22 calibre bullet projectiles with spherical tip), see Figure 15.

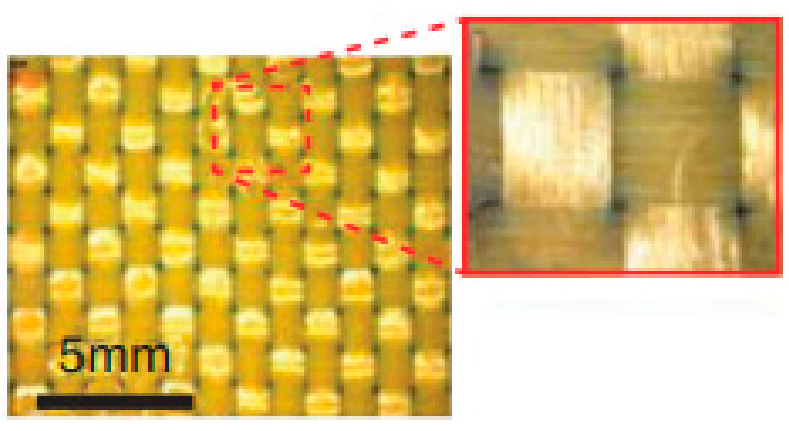

(a)

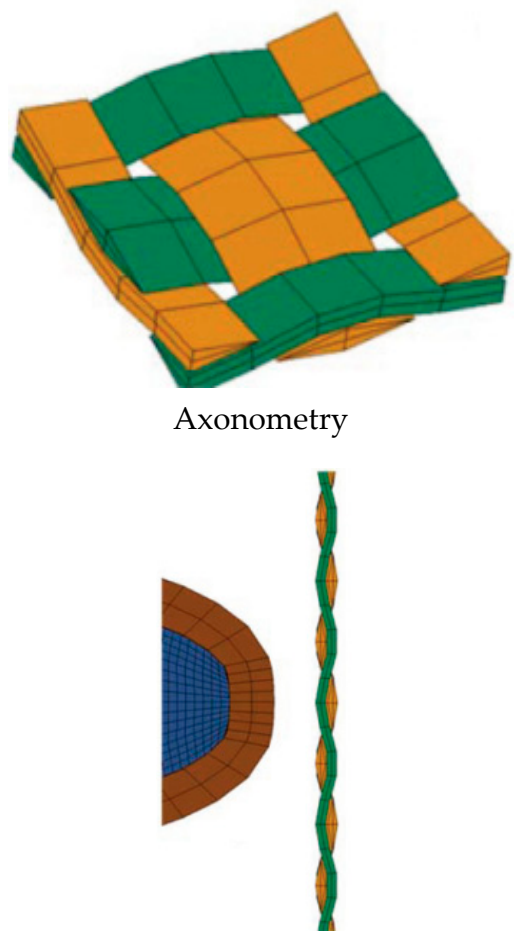

Lateral view

(c)

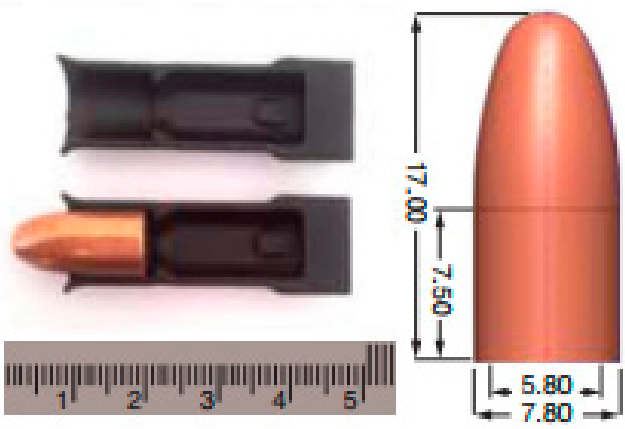

(b)

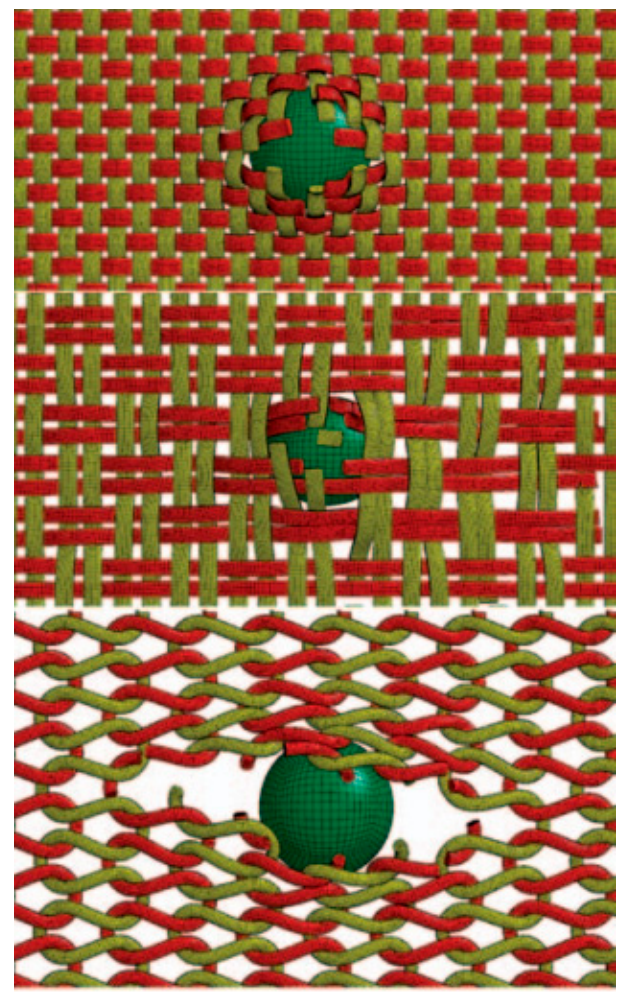

(d)

Figure 15. Refined finite element numerical modelling of textile curtains under ballistic impact, for the protection of glass facades (reproduced from [90]): (a) fabric detail; (b) bullet sabot (with nominal dimensions in $\mathrm{mm}$ ); (c) detail of the typical numerical model and (d) predicted failure patterns. 
Following [94], it is however recognized that the textile architecture can have a key role on the expected mechanical behaviour of these curtains. The study reported in [94,95], for example, was focused on jersey-knitted fabric specimens, and took into account several material compositions, fiber lengths, but also the amount of filaments, plies etc.

The fulfilment of specific performances for textile curtains under impact, in this regard, cannot disregard the effect of yarn-to-yarn and textile structural interactions. In some cases, such a goal can be assessed with the support of advanced FE numerical models (i.e., Figure 16), where careful consideration should be spent for major intrinsic features of multifilament yarns, such as, the variation of material stiffness with the loading state (i.e., due to modifications in the internal structure of yarns), crushing phenomena in the transverse plane (with respect to the yarn's longitudinal direction), etc.

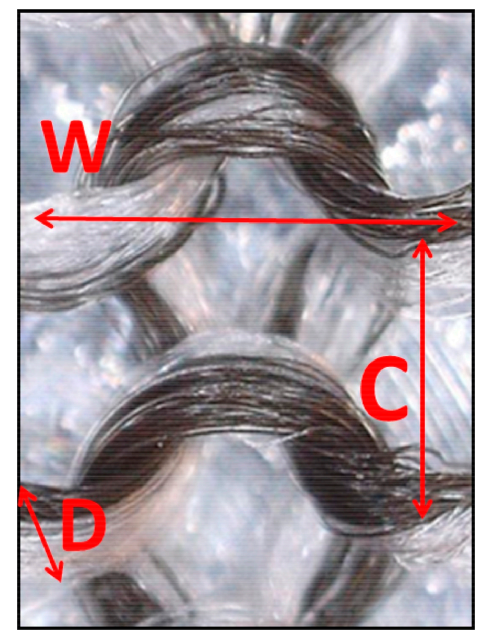

Legend

$\mathrm{C}=$ course spacing

$\mathrm{W}=$ wale spacing

$\mathrm{D}=$ yarn diameter

(a)

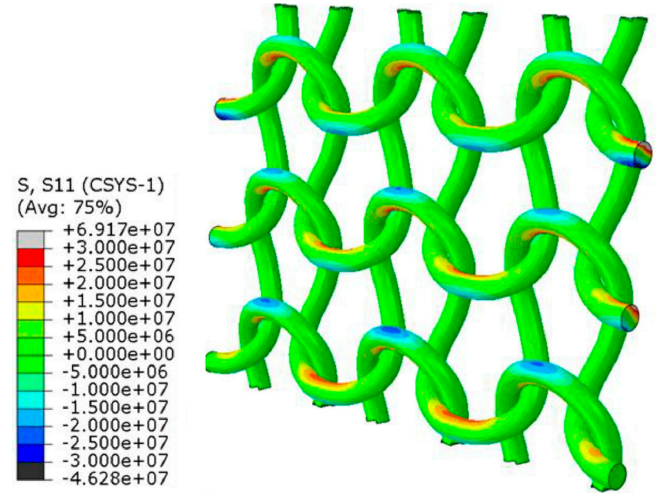

(b)

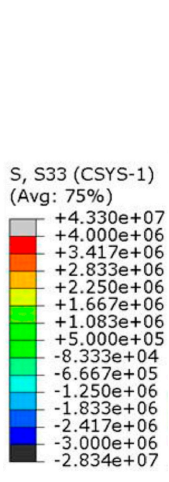

$-3.000 e+06$
$-2.834 \mathrm{e}+07$

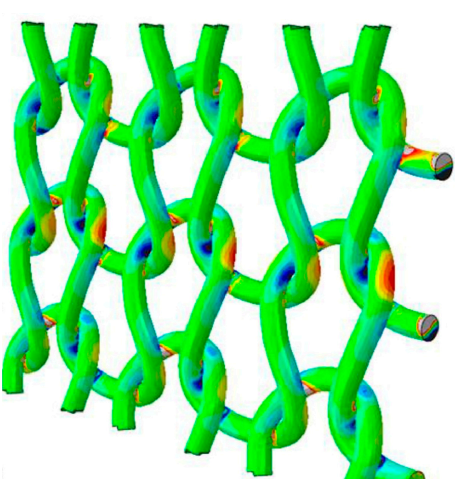

(c)

Figure 16. An example of refined FE modelling of textile structures: (a) Microscopy image of the reference knitted textile architecture, with evidence of local stresses due to mechanical interactions; (b) in-plane and (c) out-of-plane stress peaks (values in Pa; figures reproduced from [94] with permission from Elsevier, license n. 4581300089691, May 2019).

\subsection{Textiles for Acoustic and UV-Absorption Comfort and of Glass Facades}

The acoustic performance assessment of glass in buildings, finally, is another performance indicator that generally requires experiments and refined calculation studies (see for example $[96,97]$ ). At the same time, however, the same glass façade panels are the first defence from UV radiation, and UV rays themselves are responsible for severe mechanical degradation of laminated glass members (especially the interlayers, see [98-100]). 
The use of textiles for smart skins, in this regard, is often associated to the realization of membranes and coverings that are asked to interact with wide glass surfaces. This can be the case of public spaces in which people can meet and/or work, like atria, internal courts, restaurants, open spaces, etc. The experimental study summarized in [101], for example, proved that textile fabrics coated with PVB blinder matrices can offer enhanced performances against $U V$ radiations. The advantage is represented by the incorporation of different, efficient UV-absorbers, hence resulting in UV-protective coatings for textiles. The same research study, however, focused only on the UV-absorption capacity of coated textiles, and additional performance indicators should be taken into account for comparative evaluations.

While these glass panels can be frequently used to cover wide surfaces and roofs where they are able to preserve an appropriate lightening level for the interior rooms, further severe acoustic issues could derive from the so called Lombard effect, and namely consisting of a reflex of vocal chords. This phenomenon is strictly related to the vocal intensity, voice frequency, word duration, etc., but may result in unpleasant performances and thus unpleasant feelings for the occupants [102-104].

In this context, the research study carried out in [105] was focused on the acoustic comfort deriving from four different woven PES fabrics for selected scenarios of technical interest, including various weaving pattern for fabric yarns and different boundaries (see Figure 17). The investigation proved that optimal acoustic performances require dedicated (and even complex) theoretical calculations. The currently available commercial software packages for sound propagation, in this regard, were found to have crucial limits that in most of the cases were related to a weak description of key parameters and boundaries of primary interest for building engineering.

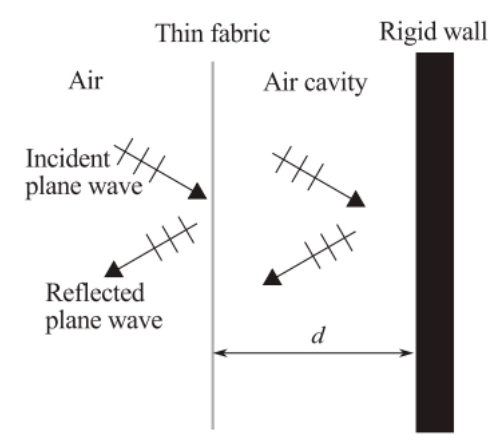

(a)

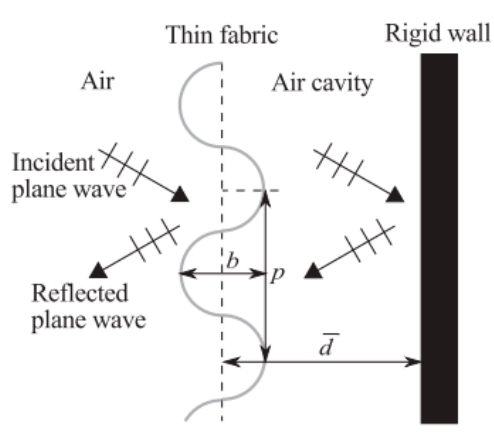

(c)

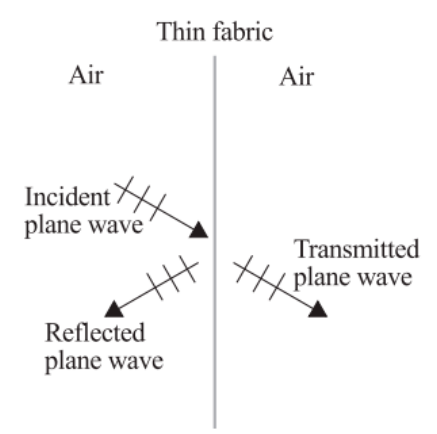

(b)

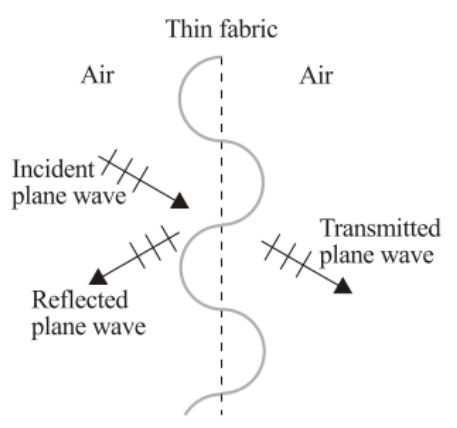

(d)

Figure 17. Textile curtains for sound insulation (reproduced from [105]). Sketch of (a) fabric sheet with rigid wall/window; (b) fabric sheet without air cavity; and folded thin curtain (c) with or (d) without rigid wall/window and air cavity. 


\section{Conclusions}

In this paper, the actual knowledge and research on the use of textiles in facades was explored, with a focus on applications of primary interest for structural glass in buildings.

Certainly, glass is relatively versatile material, but has intrinsic needs and thermo-mechanical features that require dedicated design methods and calculation approaches, towards safe design purposes. Apart from the series of advantages deriving from the use of textiles in glass facades for thermal or acoustic insulation, energy efficiency, etc., special care must be spent also for their structural requirements, at the component and assembly levels.

Textiles can offer robust support for the development of enhanced and innovative solutions for building engineering, and a multitude of functions and possibilities can be already found for the use of textiles in facades. Several decades ago, membrane structures have been mostly built in the form of attractive, large span, highly curved roof structures. Nowadays, the so called textile architecture can be found in the built environment in an even larger variety of structural skins that find application in private housing, public buildings, open spaces, etc. Typical examples include small scale shadings (i.e., to ensure protection against sun and rain), innovative components for adaptive facades (i.e., such as dynamic solar shading, or foils replacing glass elements and acting as substrates for solar energy harvesting systems, etc.), roof constructions (i.e., to preserve archaeological sites, market places, bus stations, etc.) and formworks for light shell structures.

As far as traditional glass facades are taken into account, textiles can hence offer a relatively wide series of potential uses (for energy, acoustic, thermal performance improvement, etc.), including options that are specifically intended to offer enhanced resistance to glass members. A multidisciplinary design approach able to properly fit several objectives should be necessarily considered towards the implementation and refinement of regulations, guideline documents and standardized approaches for modelling, testing and analyzing these innovative load-bearing solutions.

Author Contributions: This paper results from a joint collaboration of the authors. C.B. and V.R. both contributed to the paper drafting, collection and selection of case studies from literature, discussion and review.

Funding: The research study partly discussed in this paper was financially supported by the European COST Action CA17107 "CONTEXT - European Network to connect research and innovation efforts on advanced smart textiles". The APC was financially supported by MDPI (first author free-of-charge invitation).

Acknowledgments: The European COST Action CA17107 “CONTEXT - European Network to connect research and innovation efforts on advanced smart textiles" is gratefully acknowledged for financially supporting a scientific visit of the first author to University of Zagreb, Croatia (April 2019). A special acknowledgement is spent also for the Croatian Science Foundation (Project no. IP-2016-06-3811 - VETROLIGNUM Project - "Prototype of multipurpose timber-structural glass composite panel").

Conflicts of Interest: The authors declare no conflicts of interest.

\section{References}

1. Fangueiro, R.; Soutinho, F. Textile structures. In Fibrous and Composite Materials for Civil Engineering Applications; Woodhead Publishing: Sawston, CA, USA, 2011; Chapter 3; pp. 62-91.

2. Monjo-Carrió, J.; Tejera, J. The use of textile materials for architectural membranes. In Fibrous and Composite Materials for Civil Engineering Applications; Woodhead Publishing: Sawston, CA, USA, 2011; Chapter 12; pp. 325-387.

3. Milwich, M. Types and production of textiles used for building and construction. In Fibrous and Composite Materials for Civil Engineering Applications; Woodhead Publishing: Sawston, CA, USA, 2011; Chapter 2, pp. 13-48.

4. Hsie, M.; Tu, C.; Song, P. Mechanical properties of polypropylene hybrid fiber-reinforced concrete. Mater. Sci. Eng. A 2008, 494, 153-157. [CrossRef]

5. Rico, S.; Farshidpour, R.; Tehrani, F.M. State-of-the-Art Report on Fiber-Reinforced Lightweight Aggregate Concrete Masonry. Adv. Civ. Eng. 2017, 2017, 8078346. [CrossRef]

6. Qin, Y.; Zhang, X.; Chai, J. Damage performance and compressive behavior of early-age green concrete with recycled nylon fiber fabric under an axial load. Constr. Build. Mater. 2019, 209, 105-114. [CrossRef] 
7. Böttger, H.M.; Ostertag, C.P. Fabric Reinforcement for Improved Toughness of Adobe Block Wall Systems. Key Eng. Mater. 2014, 600, 156-165. [CrossRef]

8. Maity, S.; Singha, K. Textiles in Earth-Quake Resistant Constructions. J. Text. Sci. Eng. 2012, 2, 17-25. [CrossRef]

9. Gkournelos, D.C.; Bournas, D.A.; Triantafillou, T.C. Combined Seismic and Energy Upgrading of Existing Buildings Using Advanced Materials; Report EUR 29172 EN; Publications Office of the European Union: Luxembourg, 2019; ISBN 978-92-79-81824-0.

10. Koprivec, L.; Zbasnik-Senegacnik, M.; Kusar, J. Use of technical textiles in building engineering. Gradevinar 2006, 58, 899-907.

11. Heyse, P.; Buyle, G.; Walendy, B.; Beccarelli, P.; Loriga, G.; Zangani, D.; Tempesti, A. MULTITEXCO—High Performance Smart Multifunctional Technical Textiles for the Construction Sector. Procedia Eng. 2015, 114, 11-17. [CrossRef]

12. Annis, P.A. Understanding and Improving the Durability of Textiles; Woodhead Publishing: Sawston, CA, USA, 2012; ISBN 978-0-85709-087-4.

13. João, L.S.; Carvalho, R.; Fangueiro, R. A Study on the Durability Properties of Textile Membranes for Architectural Purposes. Procedia Eng. 2016, 155, 230-237. [CrossRef]

14. Bedon, C.; Zhang, X.; Santos, F.; Honfi, D.; Kozłowski, M.; Arrigoni, M.; Figuli, L.; Lange, D. Performance of structural glass facades under extreme loads-Design methods, existing research, current issues and trends. Constr. Build. Mater. 2018, 163, 921-937. [CrossRef]

15. Haldimann, M.; Luible, A.; Overend, M. Structural Use of Glass; IABSE: Zurich, Switzerland, 2008; ISBN 978-3-85748-119-2.

16. Feldmann, M.; Kasper, R.; Abeln, B.; Cruz, P.; Belis, J.; Beyer, J.; Colvin, J.; Ensslen, F.; Eliasova, M.; Galuppi, L.; et al. Guidance for European Structural design of glass components: Support to the implementation, harmonization and further development of the Eurocodes, Report EUR 26439. In Joint Research Centre-Institute for the Protection and Security of the Citizen; Pinto, D., Denton, F., Eds.; European Union: Luxembourg, 2014.

17. Flocker, F.; Dharani, L. Stresses in laminated glass subject to low velocity impact. Eng. Struct. 1997, 19, 851-856. [CrossRef]

18. Mohagheghian, I.; Wang, Y.; Zhou, J.; Yu, L.; Guo, X.; Yan, Y.; Charalambides, M.; Dear, J. Deformation and damage mechanisms of laminated glass windows subjected to high velocity soft impact. Int. J. Solids Struct. 2017, 109, 46-62. [CrossRef]

19. Bermbach, T.; Teich, M.; Gebbeken, N. Experimental investigation of energy dissipation mechanisms in laminated safety glass for combined blast-temperature loading scenarios. Glass Struct. Eng. 2016, 1, 331-350. [CrossRef]

20. Lu, W.; Wang, Y.; Chen, H.; Jiang, L.; Duan, Q.; Li, M.; Wang, Q.; Sun, J. Investigation of the thermal response and breakage mechanism of point-supported glass facade under wind load. Constr. Build. Mater. 2018, 186, 635-643. [CrossRef]

21. Alvarez, G.; Flores, J.J.; Estrada, C.A. The thermal response of laminated glass with solar control coating. J. Phys. D Appl. Phys. 1998, 31, 3057-3065. [CrossRef]

22. Bucak, Ö.; Albrecht, G.; Sackmann, V.; Schuler, C.; Gräf, H. Time and Temperature Dependent Mechanical Behaviour and Durability of Laminated Safety Glass. Struct. Eng. Int. 2004, 14, 80-83. [CrossRef]

23. Bedon, C.; Kozlowski, M.; Honfi, D. Thermal assessment of glass façade panels under radiant heating-Experimental and preliminary numerical studies. J. Façade Des. Eng. 2018, 6, 49-64.

24. Takeuchi, T.; Yasuda, K.; Iwata, M. Studies on Integrated Building Facade Engineering with High-Performance Structural Elements. IABSE Symp. Rep. 2006, 92, 33-40. [CrossRef]

25. Tensaform Booklet. Architectural Effects and Benefits of Textile Façade Coverings. Available online: https://www.tensaform.com (accessed on 27 June 2019).

26. Fabric Architecture Booklet. Available online: https://www.fabricarchitecture.com (accessed on 27 June 2019).

27. Nya Nordiska Innovation GMBH. Textiles Glas. 2012. Available online: https://www.architonic.com/en/ story/nya-nordiska-tex-glass-textiles-glas/7000710 (accessed on 27 June 2019).

28. CSI. Breaking the glass roof: Building with ETFE architecture. The Construction Specifier. 2016. Available online: https://www.constructionspecifier.com/breaking-the-glass-roof-building-with-etfe-architecture/2/ (accessed on 27 June 2019). 
29. COST CA17107. Memorandum of Understanding for the Implementation of the COST Action "European Network to Connect Research and Innovation Efforts on Advanced Smart Textiles"-CONTEXT. 2018. Available online: https://www.context-cost.eu (accessed on 27 June 2019).

30. Raoof, S.M.; Koutas, L.N.; Bournas, D.A. Textile-reinforced mortar (TRM) versus fibre-reinforced polymers (FRP) in flexural strengthening of RC beams. Constr. Build. Mater. 2017, 151, 279-291. [CrossRef]

31. Tetta, Z.C.; Koutas, L.N.; Bournas, D.A. Textile-reinforced mortar (TRM) versus fiber-reinforced polymers (FRP) in shear strengthening of concrete beams. Compos. Part B Eng. 2015, 77, 338-348. [CrossRef]

32. Shams, A.; Horstmann, M.; Hegger, J. Experimental investigations on Textile-Reinforced Concrete (TRC) sandwich sections. Compos. Struct. 2014, 118, 643-653. [CrossRef]

33. Raupach, M.; Cruz, C.M. Textile-reinforced concrete: Selected case studies. In Textile Fibre Composites in Civil Engineering; Woodhead Publishing: Sawston, CA, USA, 2016; Chapter 12; pp. 275-299.

34. Kimm, M.; Gerstein, N.; Schmitz, P.; Simons, M.; Gries, T. On the separation and recycling behaviour of textile reinforced concrete: An experimental study. Mater. Struct. 2018, 51, 122. [CrossRef]

35. Ehlig, D.; Jesse, F.; Curbach, M. High temperature tests on textile reinforce concrete (TRC) strain specimens. In ICTRC, Proceedings of the International RILEM Conference on Material Science, Aachen, Germany, 2010; Brameshuber, W., Ed.; RILEM Publications S.A.R.L.: Paris, France, 2010; pp. 141-151, ISBN 978-2-35158-106-3.

36. Kapsalis, P.; El Kadi, M.; De Vervloet, J.; Munck, M.; Wastiels, J.; Triantafillou, T.; Tysmans, T. Thermomechanical behavior of textile reinforced cementitious composites subjected to fire. Appl. Sci. 2009, 9, 747. [CrossRef]

37. Colombo, I.G.; Colombo, M.; Di Prisco, M.; Pouyaei, F. Analytical and numerical prediction of the bending behaviour of textile reinforced concrete sandwich beams. J. Build. Eng. 2018, 17, 183-195. [CrossRef]

38. Xu, S.; Krüger, M.; Reinhardt, H.-W.; Ožbolt, J. Bond Characteristics of Carbon, Alkali Resistant Glass, and Aramid Textiles in Mortar. J. Mater. Civ. Eng. 2004, 16, 356-364. [CrossRef]

39. Williams Portal, N. Usability of Textile Reinforced Concrete: Structural Performance, Durability and Sustainability. Ph.D. Thesis, Chalmers University of Technology, Göteborg, Swede, 2015. Available online: https://research.chalmers.se/en/publication/?id=220895 (accessed on 27 June 2019).

40. Holčapek, O.; Vogel, F.; Reiterman, P. Using of Textile Reinforced Concrete Wrapping for Strengthening of Masonry Columns with Modified Cross-section Shape. Procedia Eng. 2017, 195, 62-66. [CrossRef]

41. Heller, P.; Birk, T. Tailor made textile reinforcements in wood connections. In Proceedings of the 8th WCTE, Lahti, Finland, 14-17 June 2004; Volume 1, pp. 365-370.

42. Haller, P. Concepts for textile reinforcements for timber structures. Mater. Struct. 2007, 40, 107-118. [CrossRef]

43. Kouris, L.A.S.; Triantafillou, T.C. State-of-the-art on strengthening of masonry structures with textile reinforced mortar (TRM). Constr. Build. Mater. 2018, 188, 1221-1233. [CrossRef]

44. Lignola, G.P.; Caggegi, C.; Ceroni, F.; De Santis, S.; Krajewski, P.; Lourenço, P.B.; Morganti, M.; Papanicolaou, C.; Pellegrino, C.; Prota, A.; et al. Performance assessment of basalt FRCM for retrofit applications on masonry. Compos. Part B Eng. 2017, 128, 1-18. [CrossRef]

45. Carozzi, F.G.; Bellini, A.; D’Antino, T.; De Felice, G.; Focacci, F.; Hojdys, Ł.; Laghi, L.; Lanoye, E.; Micelli, F.; Panizza, M.; et al. Experimental investigation of tensile and bond properties of Carbon-FRCM composites for strengthening masonry elements. Compos. Part B Eng. 2017, 128, 100-119. [CrossRef]

46. De Santis, S.; Carozzi, F.G.; De Felice, G.; Poggi, C. Test methods for Textile Reinforced Mortar systems. Compos. Part B Eng. 2017, 127, 121-132. [CrossRef]

47. Gattesco, N.; Amadio, C.; Bedon, C. Experimental and numerical study on the shear behaviour of stone masonry walls strengthened with GFRP reinforced mortar coating and steel-cord-reinforced repointing. Eng. Struct. 2015, 90, 143-157. [CrossRef]

48. Kasal, B.; Heiduschke, A.; Kadla, J.; Haller, P. Laminated timber frames with composite fibre-reinforced connections. Prog. Struct. Eng. Mater. 2004, 6, 84-93. [CrossRef]

49. Haller, P.; Chen, C.-J. Textile-Reinforced Joints in Timber Construction. Struct. Eng. Int. 1999, 9, $259-261$. [CrossRef]

50. Pavković, K.; Rajčić, V.; Haiman, M. Large diameter fastener in locally reinforced and non-reinforced timber loaded perpendicular to grain. Eng. Struct. 2014, 74, 256-265. [CrossRef] 
51. Ascione, L.; Barbieri, A.; Benedetti, A.; Berardi, V.P.; Bonamini, G.; Borri, A.; Cersosimo, G.; Corradi, M.; Credali, L.; Faggiano, B.; et al. Guidelines for the Design and Construction of Externally Bonded FRP Systems for Strengthening Existing Structures-Timber Structures; CNR-DT 210/2005; Italian Research Council (CNR): Italy, 2005; Available online: https://www.cnr.it/en/node/2637 (accessed on 27 June 2019).

52. Elnokaly, A.M.; Chilton, J.C.; Wilson, R. Environmental performance of spaces enclosed or semi-enclosed by fabric membrane structures. In Textile Composites and Inflatable Structures; Onate, E., Kroplin, B.-H., Eds.; Springer: Heidelberg, Germany, 2003; p. 8521.

53. BISFA. Available online: https://www.bisfa.org (accessed on 27 June 2019).

54. BISFA. Terminology of man-made fibres. In The International Bureau for the Standardization of Man-Made Fibres; BISFA: Brussels, Belgium, 2009.

55. Stranghöner, N.; Uhlemann, J.; Bilginoglu, F.; Bltzinger, K.U.; Bögner-Balz, H.; Corne, E.; Gibson, N.; Gosling, P.; Houtman, R.; Llorens, J.; et al. Prospect for European Guidance for the Structural Design of Tensile Membrane Structures; JRC Report EUR 27716; Publications Office of the European Union: Luxembourg, 2016. [CrossRef]

56. TensiNet. Available online: https://www.tensinet.com (accessed on 27 June 2019).

57. Uhlemann, J.; Stranghöner, N. Einfluss fiktiver elastischer Konstanten von textilen Gewebemembranen in der Tragwerksanalyse von Membranstrukturen. Stahlbau 2013, 82, 643-651. [CrossRef]

58. EN ISO 1421: 2016. Rubber-or Plastics-Coated Fabrics-Determination of Tensile Strength and Elongation at Break; European Committee for Standardization (CEN): Brussels, Belgium, 2016.

59. EN 1990. Eurocode 0-Basis of Design-Annex D: Design Assisted by Testing; European Committee for Standardization (CEN): Brussels, Belgium, 2002.

60. EN 1875-3: 1997. Rubber-or Plastics-Coated Fabrics-Determination of Tear Strength-Part 3: Trapezoidal Method; European Committee for Standardization (CEN): Brussels, Belgium, 1997.

61. EN ISO 2411: 2017. Rubber- or Plastics-Coated Fabrics—Determination of Coating Adhesion; European Committee for Standardization (CEN): Brussels, Belgium, 2017.

62. Hu, H. Auxetic Textile Materials-A review. J. Text. Eng. Fash. Technol. 2017, 1, 1-15. [CrossRef]

63. Wang, Z.; Hu, H. Auxetic materials and their potential applications in textiles. Text. Res. J. 2014, 84, 1600-1611. [CrossRef]

64. Klasztorny, M.; Szurgott, P.; Niezgoda, T.; Miedzinska, D.; Kiczko, A. Preliminary comparative static identification research on selected commercial auxetic fabrics. Compos. Theory Pract. 2017, 17, 59-66.

65. Szurgott, P.; Klasztorny, M.; Niezgoda, T.; Miedzinska, D.; Gieleta, R. Dynamic Tests for Energy Absorption by Selected Auxetic Fabrics. J. Eng. Fibers Fabr. 2017, 12, 7-14.

66. Ng, W.S.; Hu, H. Tensile and Deformation Behavior of Auxetic Plied Yarns. Phys. Status Solidi 2017, 254, 1600790. [CrossRef]

67. Cerovic, M. Textile architecture: Exploring the potential of fiber assemblies and their applications in architecture. Serb. Archit. J. 2012, 4, 280-297.

68. Singh, A.V.; Rahman, A.; Sudhir Kumar, N.V.G.; Aditi, A.S.; Galluzzi, M.; Bovio, S.; Barozzi, S.; Montani, E.; Parazzoli, D. Bio-inspired approaches to design smart fabrics. Mater. Des. 2011. [CrossRef]

69. Barozzi, M.; Lienhard, J.; Zanelli, A.; Monticelli, C. The Sustainability of Adaptive Envelopes: Developments of Kinetic Architecture. Procedia Eng. 2016, 155, 275-284. [CrossRef]

70. Lüling, C.; Richter, I. Architecture Fully Fashioned-Exploration of foamed spacer fabrics for textile based building skins. J. Façade Des. Eng. 2015, 5, 77-92.

71. SEFARßArchitecture. Fabric \& Glass. Available online: http://www.sefararchitecture.com (accessed on 27 June 2019).

72. Serode, J.; Schmelzeisen, D.; Engelhardt, P.; Baumgarten, S.; Lohmann, T.; Gries, T. 4D adaptive textile building skin. In Proceedings of the Powerskin Conference, Munich, Germany, 17 January 2019; pp. 95-109, ISBN 978-9463661256.

73. Bedon, C.; Honfi, D.; Machalická, K.V.; Eliášová, M.; Vokáč, M.; Kozłowski, M.; Wüest, T.; Santos, F.; Portal, N.W. Structural characterisation of adaptive facades in Europe-Part I: Insight on classification rules, performance metrics and design methods. J. Build. Eng. 2019, 25, 100721. [CrossRef]

74. Bedon, C.; Honfi, D.; Machalicka, K.V.; Eliasova, M.; Vokac, M.; Kozlowski, M.; Wuest, T.; Santos, F.; Portal, N.W. Structural characterisation of adaptive facades in Europe-Part 2: Validity of conventional experimental testing methods and key issues. J. Build. Eng. 2019. [CrossRef] 
75. Lueling, C.; Beuscher, J. 3dTEX-Exploration of movement mechanisms for 3D-Textiles used as solar shading devices. In Proceedings of the Powerskin Conference, Munich, Germany, 17 January 2019; pp. 159-172, ISBN 978-9463661256.

76. Bedon, C.; Santos, F. Toward a novel SMA-reinforced laminated glass panel. In Advanced Engineering Materials and Modeling; Tiwari, A., Murugan, N.A., Ahuja, R., Eds.; Wiley: Hoboken, NJ, USA, 2016; pp. 87-120.

77. Bedon, C.; Dos Santos, F.A. FE Exploratory Investigation on the Performance of SMA-Reinforced Laminated Glass Panels. Adv. Eng. Mater. 2016, 18, 1478-1493. [CrossRef]

78. Feirabend, S. Reinforced laminated glass. In Challenging Glass: Conference on Architectural and Structural Applications of Glass, Faculty of Architecture, Delft University of Technology, May 2008; IOS Press: Amsterdam, The Netherlands, 2008; pp. 469-478, ISBN 978-1-58603-866-3.

79. Ølgaard, A.B.; Nielsen, J.H.; Olesen, J.F. Design of Mechanically Reinforced Glass Beams: Modelling and Experiments. Struct. Eng. Int. 2009, 19, 130-136. [CrossRef]

80. Louter, C.; Belis, J.; Veer, F.; Lebet, J.-P. Structural response of SG-laminated reinforced glass beams; experimental investigations on the effects of glass type, reinforcement percentage and beam size. Eng. Struct. 2012, 36, 292-301. [CrossRef]

81. Carvalho, P.; Cruz, P.J.S.; Veer, F. Perforated steel plate to laminated glass adhesive properties. In Proceedings of the 12th International Conference on Architectural and Automotive Glass (Glass Performance Days), Tampere, Finland, 17-20 June 2011; pp. 281-285.

82. Bedon, C.; Louter, C. Structural glass beams with embedded GFRP, CFRP or steel reinforcement rods: Comparative experimental, analytical and numerical investigations. J. Build. Eng. 2019, 22, 227-241. [CrossRef]

83. Corradi, M.; Speranzini, E. Post-Cracking Capacity of Glass Beams Reinforced with Steel Fibers. Materials 2019, 12, 231. [CrossRef] [PubMed]

84. Achintha, M.; Zirbo, T. Developments in GFRP reinforced bolted joints in glass. In Proceedings of the Challenging Glass 6 Conference on Architectural and Structural Applications of Glass, Delft, The Netherlands, 17-18 May 2018; p. 8, ISBN 978-94-6366044-0.

85. Pichandi, S.; Rana, S.; Oliveira, D.; Fangueiro, R. Fibrous and composite materials for blast protection of structural elements-A state-of-the-art review. J. Reinf. Plast. Compos. 2013, 32, 1477-1500. [CrossRef]

86. Burmistrov, I.; Vikulova, M.; Panova, L.; Yudintseva, T. Development of acrylate-based polymeric layers for fireproof laminated glass. AIP Conf. Proc. 2017. [CrossRef]

87. Heffernan, P.J.; Moyle, C.C.; Wight, R.G.; Scherbatiuk, K.D. The effectiveness of textile barriers to attenuate blast wave ingress into buildings. In Proceedings of the CSCE 1st Speciality Conference on Disaster Mitigation, Calgary, AB, Canada, 2006; p. 8.

88. Yang, C.; Tran, P.; Ngo, T.; Mendis, P.; Humphries, W. Effect of Textile Architecture on Energy Absorption of Woven Fabrics Subjected to Ballistic Impact. Appl. Mech. Mater. 2014, 553, 757-762. [CrossRef]

89. Tran, P.; Ngo, T.; Yang, E.C.; Mendis, P.; Humphries, W. Effects of architecture on ballistic resistance of textile fabrics: Numerical study. Int. J. Damage Mech. 2014, 23, 359-376. [CrossRef]

90. Yang, E.C.; Ruan, D.; Tran, P.; Ngo, T.D. Impact Resistance and Failure Analysis of Plain Woven Curtains. Int. J. Prot. Struct. 2015, 6, 113-136. [CrossRef]

91. Reyes, G.; Sharma, U. Modeling and damage repair of woven thermoplastic composites subjected to low velocity impact. Compos. Struct. 2010, 92, 523-531. [CrossRef]

92. Kerber, A.; Gargano, A.; Pingkarawat, K.; Mouritz, A. Explosive blast damage resistance of three-dimensional textile composites. Compos. Part A: Appl. Sci. Manuf. 2017, 100, 170-182. [CrossRef]

93. Stopforth, R.; Adali, S. Experimental study of bullet-proofing capabilities of Kevlar, of different weights and number of layers, with 9 mm projectiles. Def. Technol. 2019, 15, 186-192. [CrossRef]

94. Liu, D.; Christe, D.; Shakibajahromi, B.; Knittel, C.; Castaneda, N.; Breen, D.; Dion, G.; Kontsos, A. On the role of material architecture in the mechanical behavior of knitted textiles. Int. J. Solids Struct. 2017, 109, 101-111. [CrossRef]

95. Novotny, M.; Poot, B. Influence of temperature on laminated glass performances assembled with various interlayers. In Challenging Glass 5: Conference on Architectural and Structural Applications of Glass; Belis, J.L.I.F., Bos, F.P., Louter, C., Eds.; Ghent University: Gent, Belgium, 2016; p. 14, ISBN 978-90-825-2680-6.

96. Maraqa, M.A.; Hawas, Y.S.; Alam, M.D.; El Szafir, J.; Aljunadi, K.N. Laboratory testing of different window design cases for noise transmission. IOP Conf. Ser. Mater. Sci. Eng. 2018, 383, 012027. 
97. Vedrtnam, A.; Motilal Nehru National Institute of Technology Allahabad; Pawar, S.J. Invertis University Experimental and simulation studies on acoustical characterisation of laminated safety glass. Glas. Technol. Eur. J. Glas. Sci. Technol. Part A 2018, 59, 58-70. [CrossRef]

98. Duarte, I.; Rotter, A.; Malvestiti, A.; Silva, M. The role of glass as a barrier against the transmission of ultraviolet radiation: An experimental study. Photodermatol. Photoimmunol. Photomed. 2009, 25, 181-184. [CrossRef] [PubMed]

99. Serafinavicious, T.; Lebet, J.P.; Louter, C.; Kuranovas, A.; Lenkimas, T. The effects of environmental impacts on durability of laminated glass plates with interlayers (SG, EVA, PVB). In Challenging Glass 4 E COST Action TU0905 Final Conference; CRC Press: Boca Raton, FL, USA, 2014; pp. 455-462, ISBN 978-1-138-00164-0.

100. Ranocchiai, G.; Sciurpi, F.; Fagone, M. Laminated glass beams subjected to artificial solar radiation. In Challenging Glass 6, Proceedings of the Conference on Architectural and Structural Applications of Glass, Delft, The Netherlands, 17-18 May 2018; Louter, P.C., Bos, F.P., Belis, J.L.I.F., Veer, F.A., Nijsse, R., Eds.; TU Delft Open: Delft, The Netherlands, 2018; ISBN 978-94-6366-044-0. [CrossRef]

101. Grethe, T.; Schwarz-Pfeiffer, A.; Grassmann, C.; Engelhardt, E.; Feld, S.; Guo, F.; De Vrieze, M.; Mahltig, B. Polyvinylbutyral (PVB) coatings for optical modification of textile substrates. In Polymer Research: Communicating Current Advances, Contributions, Applications and Educational Aspects; Formatex Research Center: Badajoz, Spain, 2018; Chapter 5.

102. Lee, J. Noise reduction and air behaviors in ventilated single-glazed façade with glass fiber-based shading louvers and compact silencers. In Proceedings of the INTER-NOISE 2018: 47th International Congress and Exposition on Noise Control Engineering; Impact of Noise and Control Engineering, Chicago, IL, USA, 26-29 August 2018; p. 142830.

103. Urbán, D.; Zrneková, J.; Zat'ko, P.; Maywald, C.; Rychtáriková, M. Acoustic Comfort in Atria Covered by Novel Structural Skins. Procedia Eng. 2016, 155, 361-368. [CrossRef]

104. Urban, D.; Chmelík, V.; Tomašovič, P.; Rychtáriková, M. Analysis of the Acoustic Conditions in a Tent Structures. Energy Procedia 2015, 78, 489-494. [CrossRef]

105. Pieren, R.; Schaffer, B.; Schoenwald, S.; Eggenschwiler, K. Sound absorption of textile curtains-Theoretical models and validations by experiments and simulations. Text. Res. J. 2018, 88, 36-48. [CrossRef] 